\title{
Antitumor activity of organoruthenium complexes with chelate aromatic ligands, derived from 1,10-phenantroline: Synthesis and biological activity
}

\author{
Aleksandar Savića,*, Nevenka Gligorijevićb ${ }^{\mathrm{b}}$, Sandra Aranđelovićb,*, Biljana Dojčinovićc \\ Anna M. Kaczmarek ${ }^{\mathrm{d}}$, Siniša Radulović ${ }^{\mathrm{b}}$, Rik Van Deun ${ }^{\mathrm{d}}$, Kristof Van Hecke ${ }^{\mathrm{e}}$

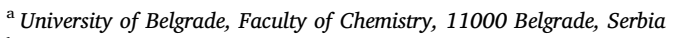 \\ ${ }^{\mathrm{b}}$ Department for Experimental Oncology, Institute for Oncology and Radiology of Serbia, Pasterova 14, 11000 Belgrade, Serbia \\ ${ }^{\mathrm{c}}$ Institute of Chemistry, Technology and Metallurgy, University of Belgrade, Njegoševa 12, 11000 Belgrade, Serbia \\ ${ }^{\mathrm{d}} \mathrm{L}^{3}$-Luminescent Lanthanide Lab, Ghent University, Department of Chemistry, B-9000 Ghent, Belgium \\ ${ }^{\mathrm{e}}$ XStruct, Ghent University, Department of Chemistry, B-9000 Ghent, Belgium
}

\section{A R T I C L E I N F O}

\section{Keywords:}

Organoruthenium complexes

Crystal structure

3D cell culture

Cytotoxicity

\begin{abstract}
A B S T R A C T
The monocationic chloro complexes containing chelating $\mathrm{N} \cap \mathrm{N}$ ligands: $\left[\left(\eta^{6}-p \text {-cymene }\right) \mathrm{Ru}(\mathrm{L} 1-4) \mathrm{Cl}\right]^{+}(1-4)$, where L1 = 4-methyl-1,10-phenantroline, L2 = dipyrido[3,2-a:2',3'-c]phenazine, L3 = 11-chloro-dipyrido[3,2a:2',3'-c]phenazine, L4 = 11-nitro-dipyrido[3,2-a:2',3'-c]phenazine; $p$-cymene = 1-methyl-4-isopropylbenzene) have been prepared and characterized as the hexafluorophosphate salts. The biological activity of 1-4 has been investigated in selected 2D monolayer cell cultures (A549, PANC-1, MDA-MB-231, MRC-5). All investigated ruthenium complexes showed similar or even better cytotoxicity to cisplatin. However, there was no significant reduction in growth of PANC-1 cells in a 3D cell culture of multicellular tumor spheroids (MCTS) after treatment with 2-4, while the cisplatin treatment induced retardation in MCTS growth. Flow cytometry analysis of the cell cycle of PANC-1 cells shows that $\mathbf{3}$ caused changes of cell cycle phase distribution characterized by slight accumulation of cells in the G2-M phase. Absence of the Sub-G1 phase in the cell cycle of the treated cells indicated that there was no fragmentation of DNA for the analyzed time intervals ( 48 and $72 \mathrm{~h}$ treatment). Fluorescent microscopy, after acridine orange/ethidium bromide staining, revealed that the investigated ruthenium complexes induced some characteristics of apoptotic morphology (shrinking and condensation of chromatin) with notably preserved integrity of the plasma membrane. Investigation of cellular uptake and DNA - fraction accumulation performed by inductively coupled plasma mass spectrometry in PANC-1 cells with equimolar concentrations $(5 \mu \mathrm{M})$ of 2-4 and cisplatin showed more efficient cellular uptake and DNA - fraction accumulation of complex 3 compared to complexes 2 and 4 .
\end{abstract}

\section{Introduction}

A modern era of metal-based anticancer drugs began with Rosenberg's discovery of cisplatin (CDDP) [1]. Thousands of platinum complexes have been synthesized in attempt to discover more effective anti-tumor drugs, however only a small number of these compounds have entered clinical trials. Nowadays, CDDP, carboplatin and oxaliplatin are used in about $50 \%$ of all cancer treatments [2-4]. A main limitation of these platinum drugs is development of resistance to their action, due to the multiple mechanism including inactivation in tumor cells by small molecules (e.g. glutathione) and ejection from the cells or due to malfunction of cellular deoxyribonucleic acid (DNA) damage response or apoptotic mechanisms [5,6]. Also, numerous side effects (nausea, vomiting, nephro-, neuro- and ototoxicity) are frequently observed in clinical application of the mentioned drugs [3]. The major task in metal-based anticancer drug design nowadays is surpassing CDDP effectiveness and overcoming CDDP resistance. Because of the complexity of this issue and the number of affecting factors, this has led to a large number of different approaches to the problem. One that has been attractive in the previous three decades is the design of ruthenium based anticancer complexes [7-10]. Unlike the platinum complexes which have shown to some extent uniformity and predictability in their biological behavior, structural diversity of ruthenium compounds has yielded different families of ruthenium antitumor agents, with different mode of actions governed by their redox potential and their relative lipophilicity/hydrophilicity, which determines their cellular uptake

\footnotetext{
* Corresponding authors.

E-mail addresses: aleksandar@chem.bg.ac.rs (A. Savić), manics@ncrc.ac.rs (S. Aranđelović).
} 
[11-18]. Even Ru complexes which are belonging to the same family with very similar structure may have totally different biological properties, so that generalization related to their mode of actions should be avoided [19]. In the literature, there are many proposed mechanisms which describe antitumor activity of ruthenium complexes: interaction with DNA [20], inhibition of kinases [21] or topoisomerases [22] inhibition of the cell cycle [23], and induction of mitochondrial dysfunction pathways [24]. Several ruthenium drugs display promising antitumor activity combined with lower toxicity in relevant in vivo models. The first ruthenium complexes, which have reached the farthest in biological investigations and entered clinical trial, are Ru(III) complexes: imidazolium-trans-tetrachloro(dimethylsulfoxide)imidazoleruthenium(III) (NAMI-A) and sodium trans-[tetrachloridobis(1H-indazole)ruthenate(III)] (KP1339, currently IT-139) [25]. Ruthenium (II) polypyridyl complexes of structural formula $\left[\mathrm{Ru}(\mathrm{bpy})_{2} \mathrm{dppz}\right]^{2+}$ (bpy $=2,2^{\prime}$-bipyridine, $\mathrm{dppz}=$ dipyrido $\left[3,2-\mathrm{a}: 2^{\prime}, 3^{\prime}\right.$-c $]$ phenazine) or $\left[\mathrm{Ru}(\text { phen })_{2} \mathrm{dppz}\right]^{2+} \quad$ (phen $=1,10$-phenanthroline), with different functional groups on the dppz ligand, demonstrated potential ability for the medical application, as photosensitizers [26,27]. The most successful photodynamic therapy (PDT) photosensitizer to date is $\left[\mathrm{Ru}\left(4,4^{\prime}\right.\right.$ dimethyl-2,2'-bipyridine $)_{2}\left(2-\left(2^{\prime}, 2^{\prime \prime}: 5^{\prime \prime}, 2^{\prime \prime \prime}\right.\right.$-terthiophene)-imidazo[4,5f])] $\mathrm{Cl}_{2}$ (TLD-1433) which phase Ib clinical trials was completed last year [28]. Ruthenium complexes containing heterocyclic base molecules have shown promising antitumor properties. For example, it was found that the complex $[\mathrm{Ru}(\mathrm{bpy})(\mathrm{phpy})(\mathrm{dppz})]^{+}$(phpy $=2$-phenylpyridine) (Fig. 1a) was rapidly taken up by cancer cells with $90 \%$ of the complex accumulated in the nuclei of cancer cells $[29,30]$, while $\left[\mathrm{Ru}(\mathrm{dppz})_{2}(\mathrm{CppH})\right]^{2+} \quad(\mathrm{CppH}=2$-(2-pyridyl)pyrimidine-4-carboxylic acid) (Fig. 1b) specifically targeted mitochondria and exhibited cytotoxicity comparable to CDDP in HeLa cells $[30,31]$. Also, it has been observed that the cytotoxicity of $\left[\mathrm{Ru}(\mathrm{bpy})_{2}(\mathrm{~N}-\mathrm{N})\right] \mathrm{Cl}_{2}$ complexes, where $\mathrm{N}-\mathrm{N}$ is bpy (Fig. 1c) or phen (Fig. 1d) or dpq = pyrazino[2,3-f] [1,10]phenanthroline (Fig. 1e) or dppz (Fig. 1f) or dppn (4,5,9,16-tetraaza-dibenzo[a,c] naphthacen) (Fig. $1 \mathrm{~g}$ ), was increasing with the size of the aromatic moiety, with drastically lowering $\mathrm{IC}_{50}$ value for $[\mathrm{Ru}$ (bpy) $\left.{ }_{2}(\mathrm{dppn})\right]^{2+}$ complex [32].

Organoruthenium complexes of the type $\left[\left(\eta^{6} \text {-arene }\right) \mathrm{Ru}^{\mathrm{II}}(\mathrm{XY}) \mathrm{Z}\right]^{+}$ (where $\mathrm{XY}$ is an N,N-, N,O-, O,O- or S,O-chelating ligand, and $\mathrm{Z}$ is a monoanionic ligand) are highly cytotoxic and reduce tumor growth in vivo. The arene ligands are strongly coordinated to the ruthenium, stabilize this metal in oxidation state +2 and provide a hydrophobic side for the passive transport through cell membranes [33-36]. Coordination of $\mathrm{N}, \mathrm{N}^{\prime}$-chelating ligands to organoruthenium(II)- species, resulted in cytotoxicity comparable to that of CDDP in a number of cell lines, including CDDP-resistant cell lines [37].

Traditional research on the efficacy of anticancer drugs is most often performed in two-dimensional (2-D) cell cultures, which may not be a genuine indicator of the in vivo effectiveness [38]. Some experimental drugs may be exclusively effective in cancer cell monolayers but noteffective in solid tumors $[39,40]$. The multicellular tumor spheroids (MCTS) are micro-sized cellular aggregates that have been widely used to assemble 3D culture models of different cancer types in vitro and are able to mimic various features of solid tumors [41]. Recently, investigation of the mechanism of action of half-sandwich Ru(II)-arene complexes of the type $\left[\left(\eta^{6}-p\right.\right.$-cymene $\left.) \mathrm{Ru}\left(\mathrm{Me}_{2} \mathrm{dppz}\right) \mathrm{Cl}\right] \mathrm{PF}_{6}, \quad(p$-cymene $=1$-methyl-4-isopropylbenzene, $\mathrm{Me}_{2} \mathrm{dppz}=11,12$-dimethyldipyrido[3,2-a:2', $3^{\prime}$-c]phenazine) has revealed that this compound acts as strong cytotoxic agent with potential of efficient cellular accumulation and ability of binding nuclear DNA with a much higher affinity than CDDP [42]. In this study, we synthesized a class of organoruthenium complexes with derivatized 1,10phenanthroline ligands, studied their structure-activity relationship and revealed the changes in biological activity resulting from structural modifications of the synthesized Ru(II) complexes.

The MCTS more accurately provide insight into the metabolic properties similar to solid tumor profiles such as nutrient and oxygen gradients, hypoxic/necrotic regions, cell-cell interactions and gene expression [39,43-45]. Hence, a 3D model was introduced in our research to investigate the efficacy of novel ruthenium complexes.

\section{Materials and methods}

\subsection{Chemistry}

$\mathrm{RuCl}_{3} \cdot \mathrm{xH}_{2} \mathrm{O}$, 4-methyl-1-(1-methylethyl)-1,3-cyclohexadiene, 4-methyl-1,10-phenanthroline (L1), potassium-bromate, o-phenylenediamine, 4-nitro-o-phenylenediamine, 4-chloro-o-phenylenediamine and $\mathrm{NH}_{4} \mathrm{PF}_{6}$ were purchased from Sigma-Aldrich, while the solvents were obtained from different commercial sources and used as received. 1,10Phenanthroline-5,6-dione [46] and the ligands dipyrido[3,2-a:2', $\left.3^{\prime}-\mathrm{c}\right]$ phenazine (L2) [47], 11-chlorodipyrido[3,2-a:2',3'-c]phenazine (L3) [48] and 11-nitrodipyrido[3,2-a:2',3'-c]phenazine (L4) [48] and were synthesized according to literature procedures with slight modifications.

Elemental analysis (C, H, N) was carried out with a Thermo Scientific Flash 2000 Series CHNS/O Analyzer. Nuclear magnetic resonance (NMR) spectra were recorded on a Bruker Avance $500 \mathrm{MHz}$ and all chemical shifts are given relative to tetramethylsilane (TMS). Standard liquid chromatography-mass spectrometry (LC-MS) analysis was performed on an Agilent 1100 series (high-performance liquid chromatography) HPLC equipped with quaternary pump and ultraviolet- diode array detector (UV-DAD), directly coupled to an Agilent G1956B single quadrupole mass spectrometer (MS) detector equipped with an electrospray ionization (ESI) source. High resolution mass spectrometry (HRMS) was performed on an Agilent 1100 series HPLC equipped with a quaternary pump and UV-DAD detector directly coupled to an Agilent 6220A series Time-of-Flight MS detector, equipped with an ESI/APCI (atmospheric pressure chemical ionization, multimode) ionization source. Infrared (IR) spectra were recorded from 4000 to $650 \mathrm{~cm}^{-1}$, on a Thermo Scientific Fourier-transform infrared (FT-IR) spectrometer (type Nicolet 6700), using $\mathrm{KBr}$ as a non-absorbing matrix.

Single-crystal X-ray diffraction measurements were performed on a Rigaku Oxford Diffraction Supernova Dual Source (Cu at zero) diffractometer equipped with an Atlas CCD detector using $\omega$ scans and CuKa $(\lambda=1.54178 \AA)$ radiation. Samples were cooled during the measurement by an Oxford Instruments Cryojet5 LN2 cryocooling at $100 \mathrm{~K}$. All images were interpreted and integrated with the program CrysAlisPro (Rigaku Oxford Diffraction) [49]. Using Olex2 [50], the structures were solved by direct methods using the ShelXS structure solution program [51] and refined by full-matrix least squares on $F^{2}$ using the ShelXL program [51,52].

\subsection{Biology}

\subsubsection{Cell culture}

The human lung carcinoma cells (A549), human pancreatic carcinoma cells (PANC-1), breast cancer cells (MDA-MB-231) and human fetal lung fibroblast cells (MRC-5) were maintained as monolayer culture in the Roswell Park Memorial Institute (RPMI) 1640 nutrient medium (Sigma Chemicals Co, USA). The human myelogenous leukemia cells (K562) were maintained in suspension culture. RPMI 1640 nutrient medium was prepared in sterile ionized water, supplemented with penicillin $(100 \mathrm{IU} / \mathrm{mL})$, streptomycin $(200 \mu \mathrm{g} / \mathrm{mL})$, 4-(2-hydroxyethyl)piperazine-1-ethanesulfonic acid (HEPES) (25 mM), L-glutamine $(3 \mathrm{mM})$ and $10 \%$ of heat-inactivated fetal calf serum (FCS) (pH 7.2). The cells were grown at $37^{\circ} \mathrm{C}$ in a humidified atmosphere containing $5 \% \mathrm{CO}_{2}$.

\subsubsection{MTT assay}

The cytotoxicity of the investigated complexes (1-4), and CDDP (as reference compound) was determined using the 3-(4,5-dymethylthiazol-yl)-2,5-diphenyltetrazolium bromide (MTT, Sigma) assay as previously described [53]. Briefly, $24 \mathrm{~h}$ after seeding the cells into 


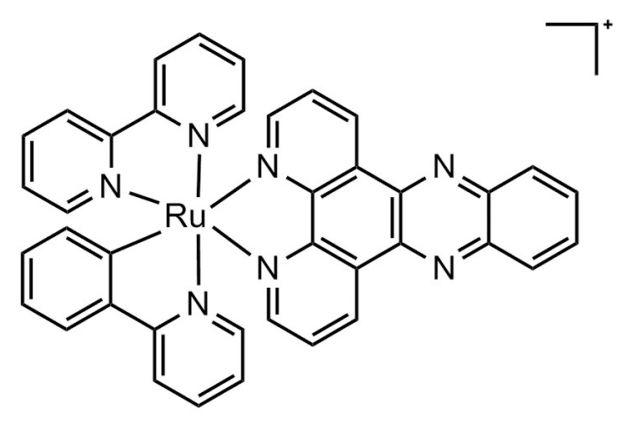

a)

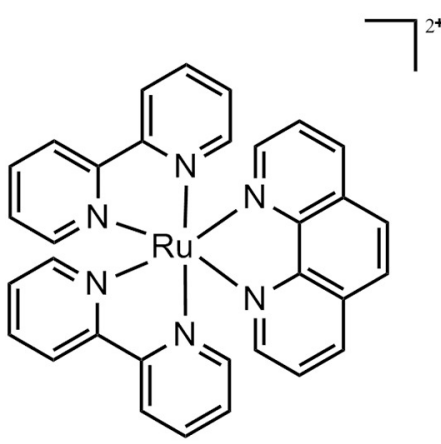

d) a)

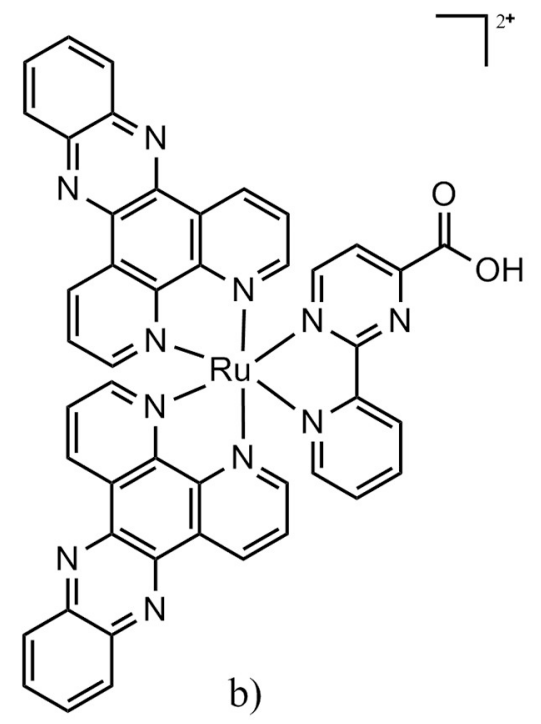

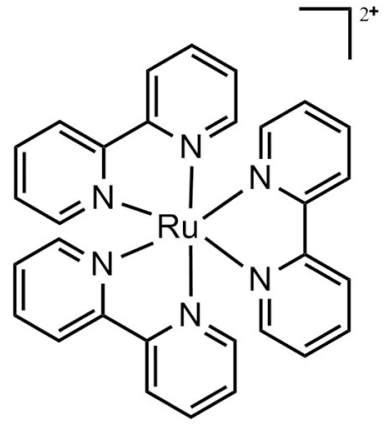

b)

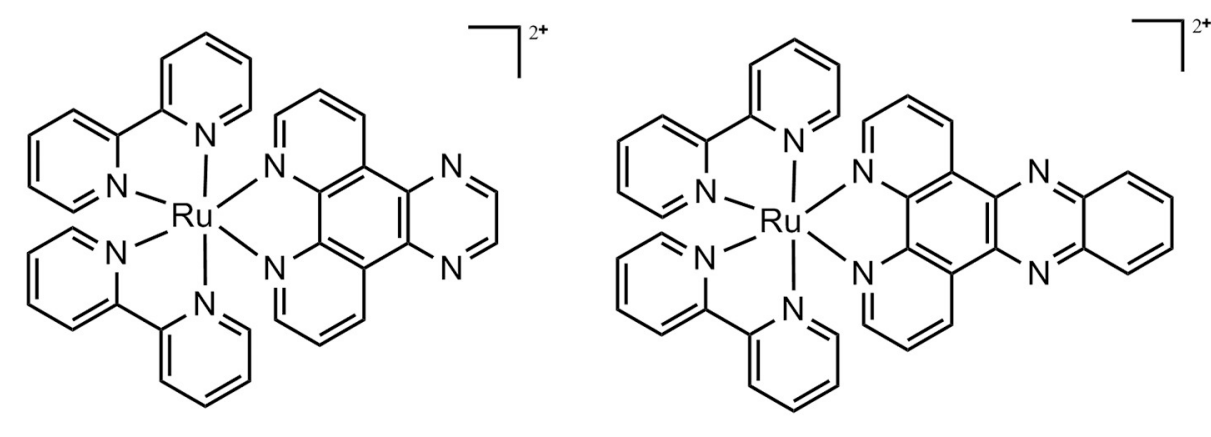

e)

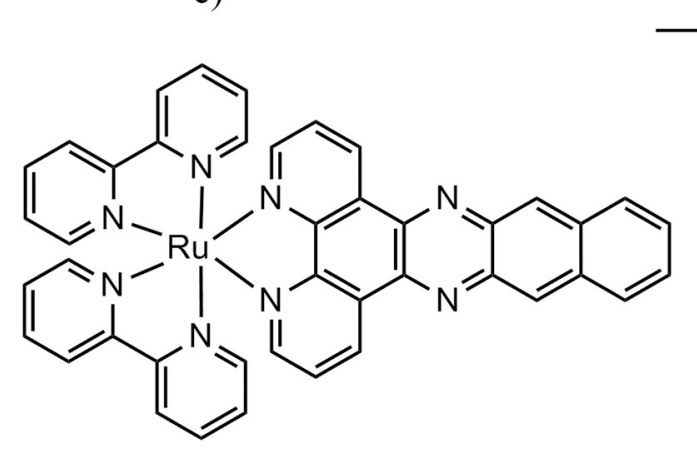

g)

Fig. 1. Structures of some ruthenium complexes with heterocyclic aromatic base as ligands: a) $[\mathrm{Ru}(\mathrm{bpy})(\mathrm{phpy})(\mathrm{dppz})]^{+}\left(\mathrm{bpy}=2,2^{\prime}\right.$-bipyridine, phpy $=2$-phenylpyridine, dppz = dipyrido[3,2-a:2', $\left.3^{\prime}-\mathrm{c}\right]$ phenazine); b) $\left[\mathrm{Ru}(\mathrm{dppz})_{2}(\mathrm{CppH})\right]^{2+}\left(\mathrm{CppH}=2\right.$-(2-pyridyl)pyrimidine-4-carboxylic acid); c) $\left[\mathrm{Ru}(\mathrm{bpy})_{3}\right]^{2+}$; d) $[\mathrm{Ru}$ $(\text { bpy })_{2}($ phen $\left.)\right]^{2+} \quad($ phen $=1,10$-phenanthroline $) ; \quad$ e) $\quad\left[R u(b p y)_{2}(\mathrm{dpq})\right]^{2+} \quad(\mathrm{dpq}=$ pyrazino $[2,3-\mathrm{f}] \quad[1,10]$ phenanthroline $\left.\left.) ; \quad \mathrm{f}\right) \quad\left[\mathrm{Ru}(\mathrm{bpy})_{2}(\mathrm{dppz})\right]^{2+} ; \mathrm{g}\right) \quad[\mathrm{Ru}$ $\left.(\text { bpy })_{2}(\mathrm{dppn})\right]^{2+}$ (dppn $=4,5,9,16$-tetraaza-dibenzo[a,c] naphthacen).

96-well cell culture plates (Thermo Scientific $\mathrm{Nunc}^{\mathrm{TM}}$ ), the cells were exposed to the investigated complexes. The complexes were dissolved in dimethyl sulfoxide (DMSO) at a concentration of $10 \mathrm{mM}$ and afterwards diluted in culture medium to the desired concentrations. The final DMSO concentration never exceeded $1 \%(v / v)$. After an incubation period of $72 \mathrm{~h}, 20 \mu \mathrm{L}$ of MTT solution $(5 \mathrm{mg} / \mathrm{mL}$ in phosphate buffer, $\mathrm{pH}$ 7.2) was added to each well. Samples were incubated for $4 \mathrm{~h}$ at $37^{\circ} \mathrm{C}$ in a humidified atmosphere of $5 \% \mathrm{CO}_{2}$, and then $100 \mu \mathrm{L}$ of $10 \%$ sodium dodecyl sulfate (SDS) was added. Absorbance was recorded after $24 \mathrm{~h}$, on an enzyme linked immunosorbent assay (ELISA) reader
(Thermo Labsystems Multiskan EX 200-240 V), at the wavelength of $570 \mathrm{~nm}$. The $\mathrm{IC}_{50}$ value, defined as the concentration of the compound causing 50\% cell growth inhibition, was determined from the cell viability diagrams.

\subsubsection{Cell cycle analysis}

Analysis of the cell cycle phase distribution of PANC-1 cells after treatment with complexes (2-4), showing the most prominent cell growth inhibitory activity, was performed by flow-cytometric analysis of the DNA content after staining with propidium iodide (PI) [54]. The 
cells were seeded at a density of $2 \times 10^{5}$ cells per well, into 6-well plates (Thermo Scientific Nunc ${ }^{\mathrm{TM}}$ ), in the nutrition medium. The cells were continually exposed to the investigated ruthenium complex 2-4 or $\mathrm{CDDP}$ at concentrations corresponding to $\mathrm{IC}_{50}, 72 \mathrm{~h}$. Control cells were incubated only in a nutrient medium or nutrition medium with DMSO. After $24 \mathrm{~h}$ or $48 \mathrm{~h}$ of growth, the cells were collected, washed twice with ice-cold phosphate-buffered saline (PBS), and fixed overnight, in $70 \%$ ethanol. After fixation, the cells were washed with PBS, and incubated with Ribonuclease A (RNaseA, $1 \mathrm{mg} / \mathrm{mL}$ ) for $30 \mathrm{~min}$, at $37^{\circ} \mathrm{C}$. Immediately before flow-cytometric analysis, the cells were stained with PI, at a concentration of $400 \mu \mathrm{g} / \mathrm{mL}$. Samples were analyzed using a fluorescence activated cell sorter (FACS), by Calibur Becton Dickinson flow cytometer, at $488 \mathrm{~nm}$ excitation line (Argon-ion laser). The data were analyzed by Cell Quest computer software.

\subsubsection{Morphological analysis of cell death by fluorescent microscopy}

The PANC-1 cells $(1 \times 10$ [5]) were seeded on coverslips into 6-well plates (ThermoScientific Nunc ${ }^{\mathrm{TM}}$ ) in $2 \mathrm{~mL}$ of the nutrient medium. After $24 \mathrm{~h}$ of growth, the cells were treated with the investigated complexes or CDDP, at $0.5 \times \mathrm{IC}_{50}$ or $1 \times \mathrm{IC}_{50}$ concentrations. Following $48 \mathrm{~h}$ and $72 \mathrm{~h}$ of treatment, the cells were stained with ethidium bromide $(3 \mu \mathrm{g} /$ $\mathrm{mL})$ and acridine orange $(5 \mu \mathrm{g} / \mathrm{mL})$, according to standard procedures $[55,56]$, and immediately after, observed under the fluorescent microscope - Carl Zeiss PALM MicroBeam with Axio Observer.Z1 using AxioCam MRm (filters Alexa Fluor 489 and Alexa Fluor 546) using the Zeiss Fluar $10 \times / 0.50$ or LD Plan-NeoFluar $20 \times / 0.4$ objectives. Images were obtained with multidimensional acquisition using digital imaging software (AxioVision Version 4.7; Carl Zeiss Imaging Solutions).

\subsubsection{Generation and analysis of MCTSs}

The multicellular tumor spheroids (MCTS) comprised exclusively of PANC-1 cells were cultured using the low attachment U96-well plate Thermo Scientific Nunclon Sphera (Nunclon Sphera 96 well U bottom plates). PANC-1 cells in the exponential growth phase were dissociated by a trypsin/ethylenediaminetetraacetic acid (trypsin/EDTA) solution to gain single-cell suspensions. A number of 500 cells/well (1000 cells/ well) were transferred to 96-well plates with $200 \mu \mathrm{L}$ of Dulbecco's Modified Eagle Medium (DMEM) containing 10\% serum. The single cells formed MCTS aggregates approximately $500 \mu \mathrm{m}$ (or minimum $500 \mu \mathrm{m}$ ) in diameter after five days with $5 \% \mathrm{CO}_{2}$ and $20 \% \mathrm{O}_{2}$ at $37^{\circ} \mathrm{C}$. The formation and growth of spheroids were examined using an Invitrogen $^{\mathrm{TM}}$ EVOS FLC ${ }^{\mathrm{TM}}$ imaging system. The PANC-1 spheroids preselected for homogeneous volume and shape were treated by carefully replacing $50 \mu \mathrm{L}$ of the medium with drug-supplemented standard medium. Three PANC-1 MCTSs were treated per condition and drug concentration.

The live/dead analysis of PANC-1 cells MCTSs was performed using two types of dual fluorescent staining: 1) Calcein-AM (Sigma-Aldrich) and PI (Sigma-Aldrich) staining and 2) the Thermo Fisher LIVE/DEAD (Blue/Green). In Calcein-AM and PI dual staining the live cells were distinguished by the presence of ubiquitous intracellular esterase activity, as determined by enzymatic conversion of the virtually nonfluorescent cell-permeant Calcein- AM to the intensely fluorescent Calcein. PI enter only cells with damaged membranes and show fluorescence upon binding to nucleic acids, thereby producing a red fluorescence in dead cells. Briefly, after treatment with the complexes, the MCTSs were incubated with Calcein-AM $(3 \mu \mathrm{M})$ and PI $(5 \mu \mathrm{M})$ solutions for $30 \mathrm{~min}$ and imaged directly using an Invitrogen $^{\mathrm{TM}}$ EVOS FLC $^{\mathrm{TM}}$ imaging system.

In a separate experiment using another type of staining Thermo Fisher LIVE/DEAD (Blue/Green) after treatment with the complexes, the MCTSs were incubated with staining solution, which was made according to the manufacturer's procedure. Briefly, 2 drops of each at room temperature, stable NucBlue ${ }^{\circledast}$ Live reagent (Hoechst 33342) and NucGreen ${ }^{\circledast}$ Dead reagent were added to $1 \mathrm{~mL}$ of cell growth media. NucBlue ${ }^{\circledast}$ Live reagent stains the nuclei of all the cells and it was detected with a standard 4',6-diamidino-2-phenylindole (DAPI) filter. NucGreen ${ }^{\circledast}$ Dead reagent stains only the nuclei of cells with compromised plasma membrane integrity and was detected using a standard green fluorescent protein (GFP) (green) filter.

\subsubsection{Cellular uptake and DNA-binding by ICP-MS}

The cellular uptake of ruthenium complexes (2-4) and CDDP after $24 \mathrm{~h}$ treatment of PANC-1 cells was investigated by measuring the intracellular ruthenium or platinum level by inductively coupled plasma mass spectrometry (ICP-MS), using a Thermo Scientific iCAP Qc ICP-MS (Thermo Scientific, Bremen, Germany) spectrometer with operational software Qtegra. The instrument was optimized and the external standards for the instrument calibration were prepared according to the previously described procedure [42]. PANC- 1 cells $(1.5 \times 10$ [6]) were seeded into $75 \mathrm{~cm}^{2}$ dishes (Thermo Scientific Nunc ${ }^{\mathrm{TM}}$ ), and at the exponential phase of growth, the cells were treated with complexes 2-4 or CDDP at equimolar concentrations of $5 \mu \mathrm{M}$. After $24 \mathrm{~h}$ of drug treatment, the cells were rinsed with PBS, detached with trypsin and counted. The cell pellet was collected by centrifugation at $2000 \mathrm{rpm}$, 10 min.

Likewise, PANC-1 cells were prepared, and the cell pellet collected using the same procedure as described above for the measurement of DNA-binding using ICP-MS. The total DNA was isolated using TRI Reagent ${ }^{\circledR}$ (Sigma Aldrich), according to the manufacturer's procedure and concentrations were determined spectrophotometrically by measuring absorbances (Eppendorf BioPhotometer 6131).

\section{Experimental part}

\subsection{General procedure for the synthesis of complexes 1-}

To a suspension of $\left[\left(\eta^{6}-p \text {-cymene }\right) \mathrm{Ru}(\mu-\mathrm{Cl}) \mathrm{Cl}\right]_{2}$ in a mixture of methanol/chloroform (15 mL, 1:1), a solution of ligand (L1 or $\mathbf{L 2}$ or $\mathbf{L 3}$ or L4) in methanol ( $5 \mathrm{~mL}$ ) was added and the reaction mixture was stirred at $40{ }^{\circ} \mathrm{C}$ during $4 \mathrm{~h}$. Then, the orange solution was concentrated under reduced pressure to $c a .7 \mathrm{~mL}$, solid $\mathrm{NH}_{4} \mathrm{PF}_{6}$ was added and the mixture was stirred at room temperature for $1 \mathrm{~h}$. A yellow-orange precipitate appeared after cooling the solution overnight at $4{ }^{\circ} \mathrm{C}$, was collected with filtration and washed with methanol $(2 \times 2.5 \mathrm{~mL})$.

\subsection{1. [(p-cymene)Ru(L1)Cl]PF}

$37 \mathrm{mg}(0.06 \mathrm{mmol})\left[\left(\eta^{6}-p \text {-cymene }\right) \mathrm{Ru}(\mu-\mathrm{Cl}) \mathrm{Cl}\right]_{2}, 23 \mathrm{mg}(0.12 \mathrm{mmol})$ 4-methyl-1,10-phenanthroline, $29 \mathrm{mg}(0.18 \mathrm{mmol}) \quad \mathrm{NH}_{4} \mathrm{PF}_{6}$. Orange crystals, suitable for X-ray diffraction, were obtained from the mother liquor at room temperature. Yield: $53 \mathrm{mg}$. HRMS: $[\mathrm{M}]^{+}$calcd. for. $\mathrm{C}_{23} \mathrm{H}_{24} \mathrm{ClN}_{2} \mathrm{Ru}^{+}$, 465.0666; found: 465.0645. IR (KBr): 3066.2, 2974.7, 2935.5, 2880.0, 1628.9, 1603.0, 1585.9, 1573.1, 1541.9, 1508.6, $1466.0,1432.3,1382.2,1229.8,1141.0,1094.3,1057.2,1030.3$, 1012.5, 908.1, 875.3, 820.4, 775.8, 728.7. ${ }^{1} \mathrm{H}$ NMR (500 MHz, DMSO$\left.d_{6}\right) \delta$ ppm: $0.90\left(\mathrm{dd}, J=6.9,3.4 \mathrm{~Hz}\right.$, arene- $\left.\mathrm{CH}\left(\mathrm{CH}_{3}\right)_{2}, 6 \mathrm{H}\right), 2.18$ (s, arene- $\mathrm{CH}_{3}, 3 \mathrm{H}$ ), 2.61 (sept, $J=6.9 \mathrm{~Hz}$, arene- $\mathrm{CH}\left(\mathrm{CH}_{3}\right)_{2}, 1 \mathrm{H}$ ), 2.98 (s, $\boldsymbol{M e}$ (phen), 3H), $6.09\left(\mathrm{t}, J=6.1 \mathrm{~Hz}\right.$, arene $\left.-\mathrm{CH}_{3}, 2 \mathrm{H}\right), 6.32(\mathrm{t}, J=6.2 \mathrm{~Hz}$, arene- $\left.\mathrm{CH}\left(\mathrm{CH}_{3}\right)_{2}, 2 \mathrm{H}\right), 8.03\left(\mathrm{~d}, \boldsymbol{H}^{3}, J=5.5 \mathrm{~Hz}, 1 \mathrm{H}\right), 8.16(\mathrm{dd}$, $\left.J=5.5 \mathrm{~Hz}, \boldsymbol{H}^{10}, 1 \mathrm{H}\right), 8.31\left(\mathrm{~d}, J=9.0 \mathrm{~Hz}, \boldsymbol{H}^{7}, 1 \mathrm{H}\right), 8.35(\mathrm{~d}, J=9.0 \mathrm{~Hz}$, $\left.\boldsymbol{H}^{6}, 1 \mathrm{H}\right), 8.93\left(\mathrm{~d}, J=8.2,5.2 \mathrm{~Hz}, \boldsymbol{H}^{9}, 1 \mathrm{H}\right), 9.77\left(\mathrm{~d}, J=5.5 \mathrm{~Hz}, \boldsymbol{H}^{11}, 1 \mathrm{H}\right)$ and 9.92 (d, $\left.J=5.4 \mathrm{~Hz}, \boldsymbol{H}^{2}, 1 \mathrm{H}\right) .{ }^{13} \mathrm{C}$ NMR $\left(125 \mathrm{MHz}\right.$, DMSO- $\left.d_{6}\right) \delta \mathrm{ppm}$ : 18.7, 22.1, 30.8, 84.1, 84.2, 86.3, 86.4, 103.1, 104.2, 124.9, 126.7, $127.4,127.5,130.1,130.3,139.1,145.2$, 145.8, 149.7, 155.7, 156.5 .

\subsection{2. $[($ p-cymene $) R u(L 2) C l] P F_{6} \quad$ (2)}

$24 \mathrm{mg}(0.04 \mathrm{mmol})\left[\left(\eta^{6} \text {-cymene }\right) \mathrm{Ru}(\mu-\mathrm{Cl}) \mathrm{Cl}\right]_{2}, 23 \mathrm{mg}(0.08 \mathrm{mmol})$ dipyrido[3,2-a:2',3'-c]phenazine (dppz), $20 \mathrm{mg}$ (0.12 mmol) $\mathrm{NH}_{4} \mathrm{PF}_{6}$. Orange crystals, suitable for X-ray diffraction, were obtained by slow diffusion of diethyl ether into the mother liquor at room temperature. Yield: $34 \mathrm{mg}$ (61\%). Anal. Calcd. for $\mathrm{C}_{28} \mathrm{H}_{24} \mathrm{ClF}_{6} \mathrm{~N}_{4} \mathrm{PRu}, \%$ : C 48.18, $\mathrm{H}$ 3.47, N 8.03. Found, \%: C 48.05, H 3.14, N 7.71. HRMS: $[\mathrm{M}]^{+}$calcd. 
for. $\mathrm{C}_{28} \mathrm{H}_{24} \mathrm{ClN}_{4} \mathrm{Ru}^{+}, 553.0728$; found: 553.0733. IR (KBr): 3083.0, 2966.0, 1604.3, 1497.3, 1470.8, 1447.3, 1422.9, 1390.9, 1357.3, $1342.8,1139.1,1093.5,1079.7,1052.5,879.0,859.0,818.0,802.5$, 767.4, 727.9. ${ }^{1} \mathrm{H}$ NMR $(500 \mathrm{MHz}$, DMSO-d $) \delta: 1.01(\mathrm{~d}, J=6.9 \mathrm{~Hz}$, arene- $\left.\mathrm{CH}\left(\mathrm{CH}_{3}\right)_{2}, 6 \mathrm{H}\right), 2.23$ (s, arene- $\left.\mathrm{CH}_{3}, 3 \mathrm{H}\right), 2.71$ (sept, $J=6.9 \mathrm{~Hz}$, arene- $\left.\mathrm{CH}\left(\mathrm{CH}_{3}\right)_{2}, 1 \mathrm{H}\right), 6.17\left(\mathrm{~d}, J=6.2 \mathrm{~Hz}\right.$, arene- $\left.\mathrm{CH}_{3}, 2 \mathrm{H}\right), 6.40(\mathrm{~d}$, $J=6.2 \mathrm{~Hz}$, arene-CH$\left.\left(\mathrm{CH}_{3}\right)_{2}, 2 \mathrm{H}\right), 8.14\left(\mathrm{dd}, J=6.3,3.3 \mathrm{~Hz}, \boldsymbol{H}^{\mathbf{1 0}}\right.$ and $\boldsymbol{H}^{11}, 2 \mathrm{H}$ ), 8.31 (dd, $J=8.2,5.3 \mathrm{~Hz}, \boldsymbol{H}^{3}$ and $\boldsymbol{H}^{14}, 2 \mathrm{H}$ ), 8.44 (dd, $J=6.3$, $3.4 \mathrm{~Hz}, \boldsymbol{H}^{9}$ and $\left.\boldsymbol{H}^{12}, 2 \mathrm{H}\right), 9.71\left(\mathrm{~d}, J=8.2 \mathrm{~Hz}, \boldsymbol{H}^{4}\right.$ and $\left.\boldsymbol{H}^{13}, 2 \mathrm{H}\right)$, and 10.02 (d, $J=5.4 \mathrm{~Hz}, \boldsymbol{H}^{2}$ and $\left.\boldsymbol{H}^{15}, 2 \mathrm{H}\right) .{ }^{13} \mathrm{C}$ NMR (125 MHz, DMSO- $\left.d_{6}\right) \delta$ ppm: 18.7, 22.2, 30.9, 84.7, 86.4, 103.2, 105.3, 128.1, 129.9, 129.9, 133.0, 135.8, 139.7, 142.4, 148.5, 157.8 .

\subsection{3. $[(p$-cymene $) R u(L 3) C l] P F_{6} \quad$ (3)}

$25 \mathrm{mg}(0.04 \mathrm{mmol})\left[\left(\eta^{6}-p \text {-cymene }\right) \mathrm{Ru}(\mu-\mathrm{Cl}) \mathrm{Cl}\right]_{2}, 25 \mathrm{mg}(0.08 \mathrm{mmol})$ 11-chloro-dipyrido[3,2-a:2',3'-c]phenazine (Cl-dppz), $21 \mathrm{mg}$ $(0.13 \mathrm{mmol}) \mathrm{NH}_{4} \mathrm{PF}_{6}$. Orange crystals, suitable for X-ray diffraction, were obtained by slow diffusion of diethyl ether in the mother liquor at room temperature. Yield $34 \mathrm{mg}$ (58\%). HRMS: $[\mathrm{M}]^{+}$calcd. for. $\mathrm{C}_{28} \mathrm{H}_{23} \mathrm{Cl}_{2} \mathrm{~N}_{4} \mathrm{Ru}^{+}$, 587.0338; found: 587.0322. IR (KBr): 3125.4, 2964.6, 1597.7, 1494.6, 1473.1, 1445.4, 1414.3, 1391.4, 1354.0, $1141.4,1080.9,1062.1,933.1,841.8,779.1,742.6,726.8 .{ }^{1} \mathrm{H}$ NMR (500 MHz, acetone- $\left.d_{6}\right) \delta$ ppm: $1.14\left(\mathrm{~d}, J=7.0 \mathrm{~Hz}\right.$, arene- $\mathrm{CH}\left(\mathrm{CH}_{3}\right)_{2}$, $6 \mathrm{H}$ ), 2.36 (s, arene- $\mathrm{CH}_{3}, 3 \mathrm{H}$ ), 2.90 (sept, $J=6.9 \mathrm{~Hz}$, arene- $\mathrm{CH}\left(\mathrm{CH}_{3}\right)_{2}$, $1 \mathrm{H}), 6.21\left(\mathrm{~d}, J=6.3 \mathrm{~Hz}\right.$, arene- $\left.\mathrm{CH}_{3}, 2 \mathrm{H}\right), 6.44(\mathrm{~d}, J=6.4 \mathrm{~Hz}$, arene-CH $\left.\left(\mathrm{CH}_{3}\right)_{2}, 2 \mathrm{H}\right), 8.17$ (dd, $\left.J=9.2,2.3 \mathrm{~Hz}, \boldsymbol{H}^{11}, 1 \mathrm{H}\right), 8.38$ (ddd, $J=8.2$, 5.4, 2.0 Hz, $\boldsymbol{H}^{9}$ and $\left.\boldsymbol{H}^{12}, 2 \mathrm{H}\right), 8.40-8.54\left(\mathrm{~m}, \boldsymbol{H}^{3}\right.$ and $\left.\boldsymbol{H}^{3}, 2 \mathrm{H}\right), 9.83$ (ddd, $J=8.2,2.1,1.3 \mathrm{~Hz}, \boldsymbol{H}^{4}$ and $\boldsymbol{H}^{13}, 2 \mathrm{H}$ ), and 10.02 (ddd, $J=5.5,2.2$, $1.4 \mathrm{~Hz}, \boldsymbol{H}^{2}$ and $\left.\boldsymbol{H}^{\mathbf{1 5}}, 2 \mathrm{H}\right) .{ }^{13} \mathrm{C}$ NMR $\left(125 \mathrm{MHz}\right.$, acetone- $\left.d_{6}\right) \delta$ ppm: 18.9 , 22.3, 31.9, 85.5, 87.1, 104.3, 106.9, 128.6, 129.1, 132.3, 134.1, 136.6, 138.7, 141.2, 149.7, 158.2.

\subsection{4. $[(p$-cymene $) R u(L 4) C l] P F_{6} \quad$ (4)}

$31 \mathrm{mg}(0.05 \mathrm{mmol})\left[\left(\eta^{6}-p \text {-cymene }\right) \mathrm{Ru}(\mu-\mathrm{Cl}) \mathrm{Cl}\right]_{2}, 33 \mathrm{mg}(0.10 \mathrm{mmol})$ 11-nitro-dipyrido[3,2-a:2', $3^{\prime}$-c]phenazine $\quad\left(\mathrm{NO}_{2}\right.$-dppz $), \quad 24 \mathrm{mg}$ (0.15 mmol) $\mathrm{NH}_{4} \mathrm{PF}_{6}$. Yield $40 \mathrm{mg}$ (54\%). Anal. Calcd. for $\mathrm{C}_{28} \mathrm{H}_{23} \mathrm{ClF}_{6} \mathrm{~N}_{5} \mathrm{O}_{2} \mathrm{PRu}, \%$ : C 45.26, H 3.12, N 9.43. Found, \%: C 45.45, $\mathrm{H}$ 2.86, N 9.59. HRMS: $[\mathrm{M}]^{+}$calcd. for. $\mathrm{C}_{28} \mathrm{H}_{23} \mathrm{ClN}_{5} \mathrm{O}_{2} \mathrm{Ru}^{+}, 598.0573$; found: 598.0573. IR (KBr): $3093.5,2970.6,1608.5,1523.8,1495.3$, 1419.3, 1349.1, 1073.6, 1051.7, 877.2, 844.3, 745.0, 738.5, 729.4. ${ }^{1} \mathrm{H}$ NMR $\left(500 \mathrm{MHz}\right.$, DMSO- $\left.d_{6}\right) \delta \mathrm{ppm}$ : $1.00(\mathrm{~d}, J=6.9 \mathrm{~Hz}$, arene-CH $\left(\mathrm{CH}_{3}\right)_{2}, 6 \mathrm{H}$ ), 2.22 (s, arene- $\mathrm{CH}_{3}, 3 \mathrm{H}$ ), 2.70 (sept, $J=6.8 \mathrm{~Hz}$, arene-CH $\left.\left(\mathrm{CH}_{3}\right)_{2}, 1 \mathrm{H}\right), 6.17\left(\mathrm{~d}, J=6.3 \mathrm{~Hz}\right.$, arene- $\left.\mathrm{CH}_{3}, 2 \mathrm{H}\right), 6.41(\mathrm{~d}, J=6.2 \mathrm{~Hz}$, arene- $\left.\mathrm{CH}\left(\mathrm{CH}_{3}\right)_{2}, 2 \mathrm{H}\right), 8.33\left(\mathrm{dt}, J=8.2,5.3 \mathrm{~Hz}, \boldsymbol{H}^{3}\right.$ and $\left.\boldsymbol{H}^{\mathbf{1 4}}, 2 \mathrm{H}\right), 8.66$ and $8.78\left(\mathrm{~d}, J=9.3 \mathrm{~Hz}, 1 \mathrm{H}\right.$ and $\mathrm{dd}, J=9.4,2.6 \mathrm{~Hz}, \boldsymbol{H}^{9}$ and $\left.\boldsymbol{H}^{12}, 1 \mathrm{H}\right)$, $9.24\left(\mathrm{~s}, \boldsymbol{H}^{11}, 1 \mathrm{H}\right), 9.72\left(\mathrm{~d}, J=8.1 \mathrm{~Hz}, \boldsymbol{H}^{4}\right.$ and $\left.\boldsymbol{H}^{\mathbf{1 3}}, 2 \mathrm{H}\right)$, and 10.05 (dd, $J=5.5,1.4 \mathrm{~Hz}, \boldsymbol{H}^{2}$ and $\left.\boldsymbol{H}^{15}, 2 \mathrm{H}\right) .{ }^{13} \mathrm{C}$ NMR $\left(125 \mathrm{MHz}\right.$, DMSO- $\left.d_{6}\right) \delta$ ppm: 20.3, 23.8, 32.5, 86.3, 87.0, 104.0, 106.0, 127.4, 129.0, 131.2, 133.5, 137.9, 142.5, 143.0, 145.7, 150.6, 160.0.

\section{Results and discussion}

\subsection{Synthesis and characterization of the complexes 1-4}

By exploring the $\mu$-chlorido-bridge splitting reaction of $\left[\left(\eta^{6}-p\right.\right.$ cymene)RuCl $]_{2}$ with $\mathrm{L} 1-\mathrm{L} 4$ in methanol/chloroform at $40^{\circ} \mathrm{C}$, with subsequent addition of ammonium hexafluorophosphate, complexes (1-4), general formula, $\left[\left(\eta^{6}-p \text {-cymene }\right) \mathrm{Ru}(\mathrm{L}) \mathrm{Cl}\right]^{+} \mathrm{PF}_{6}{ }^{-}$, have been prepared in good yields (Scheme 1).

Complex 2 has already been described in the literature, however, antitumor activity and crystal structure for $\mathbf{2}$ have not been reported yet. All complexes were characterized by elemental analysis, mass spectrometry, IR and NMR spectroscopy. Additionally, complexes 1, 2 and 3 were characterized by X-ray crystallography.

The IR spectra of all complexes showed characteristic bands at the following positions of wave numbers: around $3100 \mathrm{~cm}^{-1}(\mathrm{C}-\mathrm{H}$ stretching vibrations), $1600-1585$ and $1500-1400 \mathrm{~cm}^{-1}$ (C-C and $\mathrm{C}-\mathrm{N}$ stretching vibrations in the ring, respectively) and $900-675 \mathrm{~cm}^{-1}$ (out-of-plane bands).

The ${ }^{1} \mathrm{H}$ NMR and ${ }^{13} \mathrm{C}$ NMR spectra of the complexes showed characteristic resonances of $\eta^{6}-p$-cymene and the heterocyclic base moiety. Upon complexation to the metal, the symmetry of the ligand environment is lowered. This is observed in the cymene ring protons which appear as two doublets in the range of 6.09-6.44 ppm, in contrast to the one signal observed in $\left[\left(\eta^{6}-p \text {-cymene }\right) \mathrm{RuCl}_{2}\right]_{2}$. The characteristic septet at 2.70 or $2.90 \mathrm{ppm}$ is assigned to one proton from the isopropyl group of the $p$-cymene moiety. Signals in the range of $0.90-1.14 \mathrm{ppm}$ and 2.18-2.36 ppm correspond to protons from $-\mathrm{CH}\left(\mathrm{CH}_{3}\right)_{2}$ and $\mathrm{CH}_{3}$ (arene) of the $p$-cymene. All signals originated from the heterocyclic base moiety were found in the region of 8.03-10.05 ppm.

The mass spectra of $1-4$ recorded in acetonitrile contain peaks assigned to the $\left[\mathrm{M}^{+}-\mathrm{PF}_{6}{ }^{-}\right]$ions, which agrees with their calculated molecular mass. Molecular ions of the complexes were detectable with $\mathrm{m} / \mathrm{z}$ at 465.0645 for $\mathbf{1}, \mathrm{m} / \mathrm{z}$ at 553.0733 for $2, \mathrm{~m} / \mathrm{z}$ at 587.0322 for 3 and $\mathrm{m} / \mathrm{z}$ at 598.0573 for 4 .

X-ray diffraction studies for 1-3 showed a common "piano-stool geometry", with coordination of the heterocyclic base ligands through the nitrogen donor atoms (see Fig. 2).

Compound 1 and 2 both crystallized in the monoclinic centrosymmetric space group $P 2_{1} / \mathrm{c}$. The asymmetric unit of 1 consists of one [ $\left[\eta^{6}-\right.$ $p$-cymene)Ru(L1)Cl $]^{+}$complex and one $\mathrm{PF}_{6}{ }^{-}$counterion, while for $\mathbf{2}$, the asymmetric unit contains two $\left[\left(\eta^{6}-p \text {-cymene }\right) \mathrm{Ru}(\mathrm{L} 2) \mathrm{Cl}\right]^{+}$complexes, two $\mathrm{PF}_{6}{ }^{-}$counterions and one co-crystallized diethyl ether solvent molecule. Compound $\mathbf{3}$ crystallized in the non-centrosymmetric orthorhombic space group $\mathrm{Pnc} 2$ with three $\left[\left(\eta^{6}-p \text {-cymene }\right) \mathrm{Ru}(\mathrm{L} 3) \mathrm{Cl}\right]^{+}$ complexes, two complete $\mathrm{PF}_{6}{ }^{-}$and two half's of $\mathrm{PF}_{6}{ }^{-}$(both on a 2-fold axis) counterions in the asymmetric unit.

For all three complexes, the Ru(II) center shows a pseudo-tetrahedral coordination by the $p$-cymene in a $\eta^{6}$ mode, one $\mathrm{Cl}^{-}$anion and the $N, N^{\prime}$-chelating L ligands. The complexes all adopt the typical 'piano' stool conformation, which is illustrated by the N-Ru1-Cl1 angles of the complexes being in the range of $83.0(4)-86.28(7)^{\circ}$.

\subsection{Cell sensitivity to ruthenium complexes}

The cytotoxic activity of the investigated ruthenium complexes, and CDDP (as reference compound), against a panel of human cancer cell lines (K562, A549, PANC-1 and MDA-MB-231) and one normal cell line (MRC-5), was determined by an MTT assay. The activity was measured after $72 \mathrm{~h}$ incubation with the investigated complexes and the results are presented in Table 1, and Fig. 3. The remarkably high cell growth inhibitory activity, with $\mathrm{IC}_{50}$ values ranging from 5 to $9 \mu \mathrm{M}$, was revealed for complexes 2-4, against PANC-1 and MDA-MB-231 cells. The activity of these complexes was about 2 to 3 times higher than that of CDDP. Human myelogenous leukemia cells (K562) showed high sensitivity to all tested complexes with $\mathrm{IC}_{50}$ values being lower than CDDP (up to $7 \mu \mathrm{M}$ ). Our results indicated that minor changes in the dppz ligand, like the introduction of a strongly electron-withdrawing group $-\mathrm{NO}_{2}(4)$ or a weakly electron-withdrawing group $-\mathrm{Cl}$ group (3), were not sufficient to induce important differences in the cell growth inhibitory activity, compared to the complex with unsubstituted dppz ligand (2). The complex with substituted phen ligand (1) also had notable activity on MDA-MB-231 cells ( IC $_{50}$ up to $7 \mu \mathrm{M}$, see Table 1 ). It should be noted that in the present study cisplatin as referent compound, only showed higher cell growth inhibitory activity and selectivity, toward lung adenocarcinoma cells (A549). While most of the tested complexes (2-4), had nearly two times higher activity in leukemia cell (K562), or pancreatic adenocarcinoma (PANC-1), or breast adenocarcinoma (MDA-MB-231), than in normal human fibroblasts cells (MRC-5), thus showing greater potential for selective action in tumor cell lines, than CDDP. 


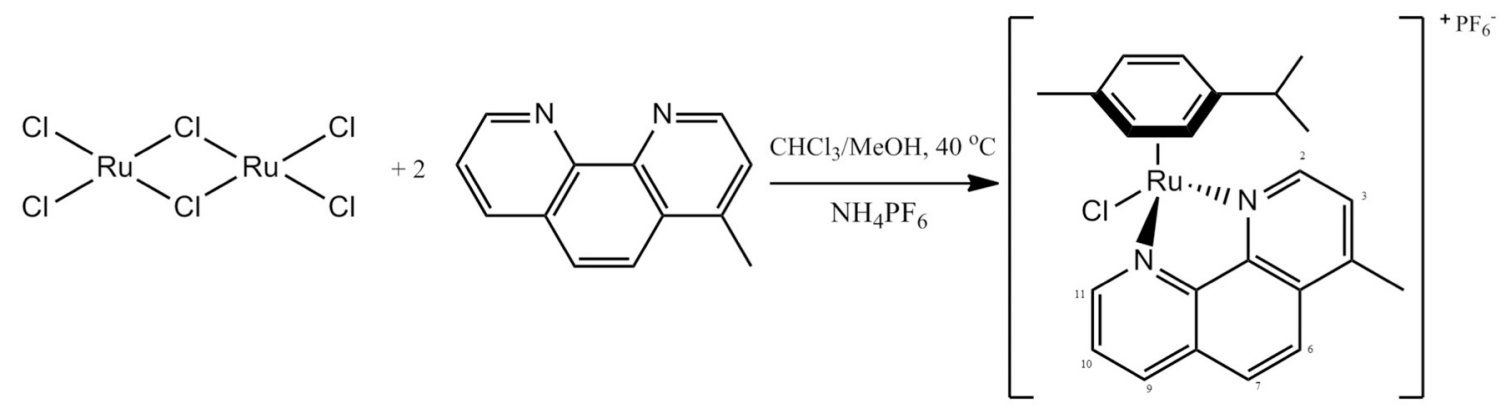

(1)

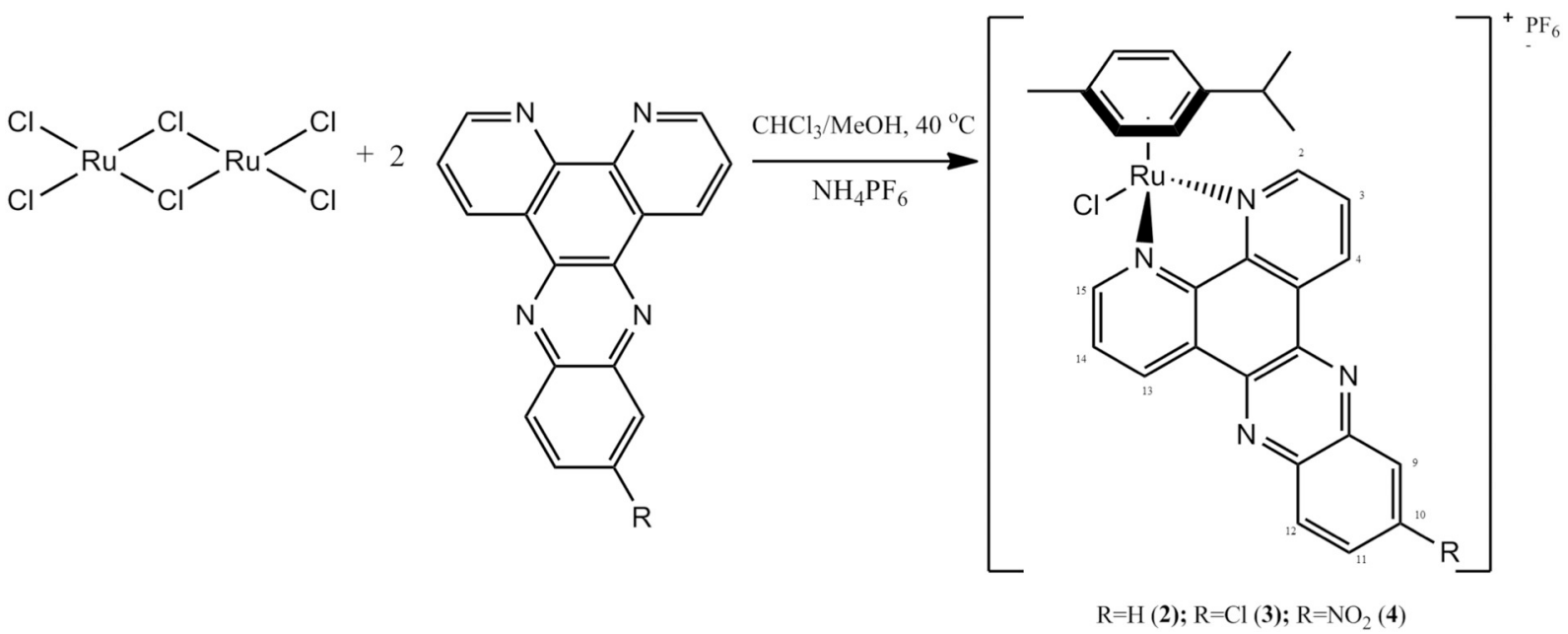

Scheme 1. Synthesis of the complexes 1-4.

\subsection{Analysis of cell cycle perturbations}

The effect of complexes 2-4 and CDDP on the cell cycle progression of PANC-1 cells was examined using PI staining and flow cytometry analysis. The results of the cell cycle analysis after treatment with concentrations corresponding to $\mathrm{IC}_{50} 72 \mathrm{~h}$ values (see Table 1 ) are determined at two points of time ( $48 \mathrm{~h}$ and $72 \mathrm{~h}$ ) and presented in Fig. 4.
After $48 \mathrm{~h}$ incubation, only complex 3 caused minor change of the cell cycle phase distribution, characterized by accumulation of cells in the G2-M phase $(52.09 \%$ vs control $42.01 \%)$. After prolonged treatment (72 h), complex 3 caused further accumulation of cells in the G2 phase. Minor accumulation of cells in the Sub-G1 phase, as characteristic of discontinuous fragmentation of nuclear DNA, was noticed only for CDDP-treated cells. CDDP, after $48 \mathrm{~h}$, induced blocking of the cell cycle a)

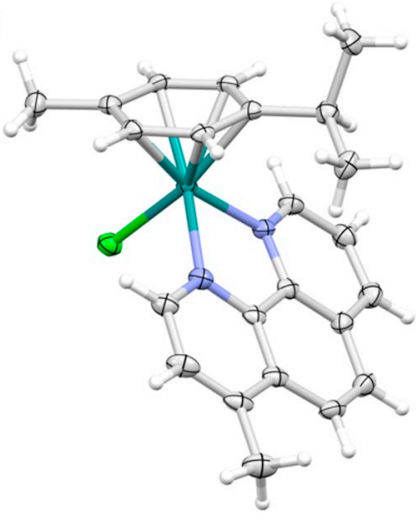

b)

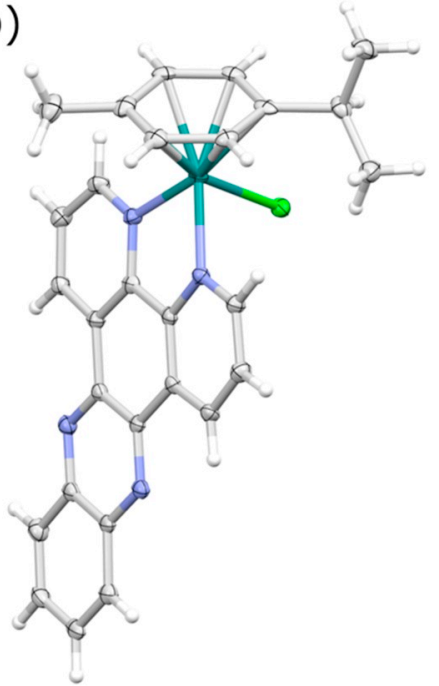

c)

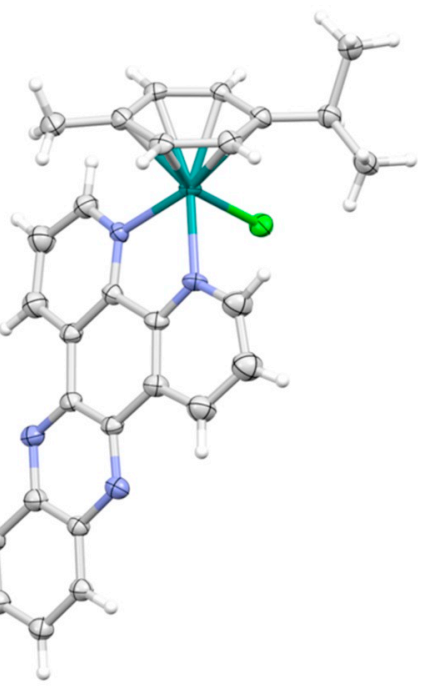

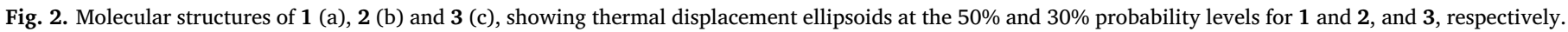
Only one molecule of the asymmetric units is shown. $\mathrm{PF}_{6}{ }^{-}$counterions and the diethyl ether solvent molecule for compound 3 are omitted for clarity. 
Table 1

The cytotoxic activity of complexes 1-4 and CDDP as reference compound determined after $72 \mathrm{~h}$ treatment by the MTT assay.

\begin{tabular}{|c|c|c|c|c|c|}
\hline \multirow[t]{2}{*}{ Compound } & \multicolumn{5}{|l|}{$\mathrm{IC}_{50}(\mu \mathrm{M})$} \\
\hline & K562 & A549 & PANC-1 & MDA-MB-231 & MRC-5 \\
\hline 1 & $6.65 \pm 0.07$ & $26.85 \pm 7.67$ & $21.26 \pm 0.98$ & $7.44 \pm 2.75$ & $4.23 \pm 0.63$ \\
\hline 2 & $6.23 \pm 2.26$ & $19.45 \pm 3.37$ & $5.49 \pm 0.64$ & $5.60 \pm 0.03$ & $8.62 \pm 3.61$ \\
\hline 3 & $6.35 \pm 1.51$ & $9.23 \pm 1.40$ & $8.47 \pm 2.21$ & $9.06 \pm 4.48$ & $13.92 \pm 4.04$ \\
\hline 4 & $6.77 \pm 1.86$ & $18.89 \pm 2.08$ & $5.66 \pm 0.37$ & $5.41 \pm 0.57$ & $9.98 \pm 1.85$ \\
\hline CDDP & $10.86 \pm 0.55^{\mathrm{b}}$ & $5.93 \pm 0.66^{\mathrm{a}}$ & $16.44 \pm 1.56$ & $14.54 \pm 0.05$ & $10.54 \pm 0.21$ \\
\hline
\end{tabular}

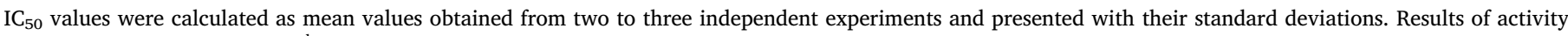
previously reported $[57]^{\mathrm{a}},[58]^{\mathrm{b}}$.

in the S phase, which led to further increase of the percentage of cells in the sub-G1 phase determined after $72 \mathrm{~h}$ treatment.

Unique properties of transition metal complexes may allow specific interactions with DNA [59]. These interactions can arise due to covalent/coordinative or subtle non-coordinative interactions such as electrostatic attraction, groove binding and intercalation as well as combinations all these modes [59]. The dppz ligand in $\mathbf{2}$ allows extensive intercalative stacking in DNA base pairs. With few exceptions, most of the Ru-dppz complexes interact strongly to the DNA duplex through intercalation [60].

In a recent study in HeLa cells, flow cytometry analysis of cell cycle perturbation induced by a very similar ruthenium complex $\left[\left(\eta^{6}-p\right.\right.$ cymene)Ru(Me $\mathrm{Appz}_{2} \mathrm{Cl} \mathrm{PF}_{6}$, revealed concentration- and time-dependent arrest of the cell cycle in G2-M and S phases. This event is followed by the accumulation of cells in sub-G1 phase after $48 \mathrm{~h}$, in levels higher than CDDP [42]. These changes in the cell cycle of HeLa cells strongly suggested direct DNA binding of this complex. While in the present study, absence of notable cell cycle perturbations (complexes 2 and 4), and absence of Sub-G1 peak (complex 3), in PANC-1 cells, may be explained by drug resistant and very complicated nature of pancreatic cancer cells [61]. Resistance mechanisms probably prevented DNA fragmentation characteristic for an apoptotic type of cell death. Results of morphological analysis of PANC-1 cell death, induced by complexes 2-4, confirmed that only few characteristics of apoptosis were detected, and that further analysis is necessary for defining the accurate type of cell death.

\subsection{Results of cellular uptake and DNA-binding by ICP-MS}

Nowadays, cellular uptake studies are becoming an essential part of the development and investigations of novel metal-based drugs. As DNA is being generally accepted as the critical target for platinum-based antitumor agents, DNA binding studies have become an integrative part of this type of research [62].

Cellular uptake and DNA binding of PANC- 1 cells of the investigated ruthenium complexes 2-4 and CDDP was determined by ICP-MS after $24 \mathrm{~h}$ treatment with $5 \mu \mathrm{M}$ concentrations of complexes $\left(\sim \mathrm{IC}_{50}\right)$ and CDDP.

ICP-MS analysis revealed surprisingly more efficient cellular uptake of complex 3, compared to complexes 2 and 4 (Fig. 5A). Intracellular accumulation of complex 3 ( $6492.90 \mathrm{ngRu} / 10^{6}$ cells) exceeded, six and ten times respectively, the level of intracellular accumulation of complex 2 (1069.97 $\mathrm{ngRu} / 10^{6}$ cells), and complex $4\left(675.06 \mathrm{ngRu} / 10^{6}\right.$ cells). The results of the DNA binding demonstrated a similar trend, showing three to four times higher DNA binding of complex 3 (1.6 ngRu/ $\mu g D N A)$, compared to complex $2(0.6 \mathrm{ngRu} / \mu \mathrm{gDNA})$ and complex 4 (0.4 ngRu/ $\mu g D N A)$ (Fig. 5B). Enhanced intracellular uptake and DNA binding of complex 3, apparently, are not directly proportional to its cell growth inhibitory activity, in the 2D model system (see section results of MTT assay, Table 1). Complexes 2 and 4 showed rather similar level of intracellular uptake and slightly higher level of DNA binding, compared to CDDP. Interactions of ruthenium complexes 2-4 with the DNA, are anticipated to be intercalative, due to the (un) substituted dipyrido[3,2-a:2', $3^{\prime}$-c]phenazine ligand, which would be different to the known mechanism of CDDP action [63].

CDDP showed considerably lower cellular uptake $\left(653.93 \mathrm{ngPt} / 10^{6}\right.$

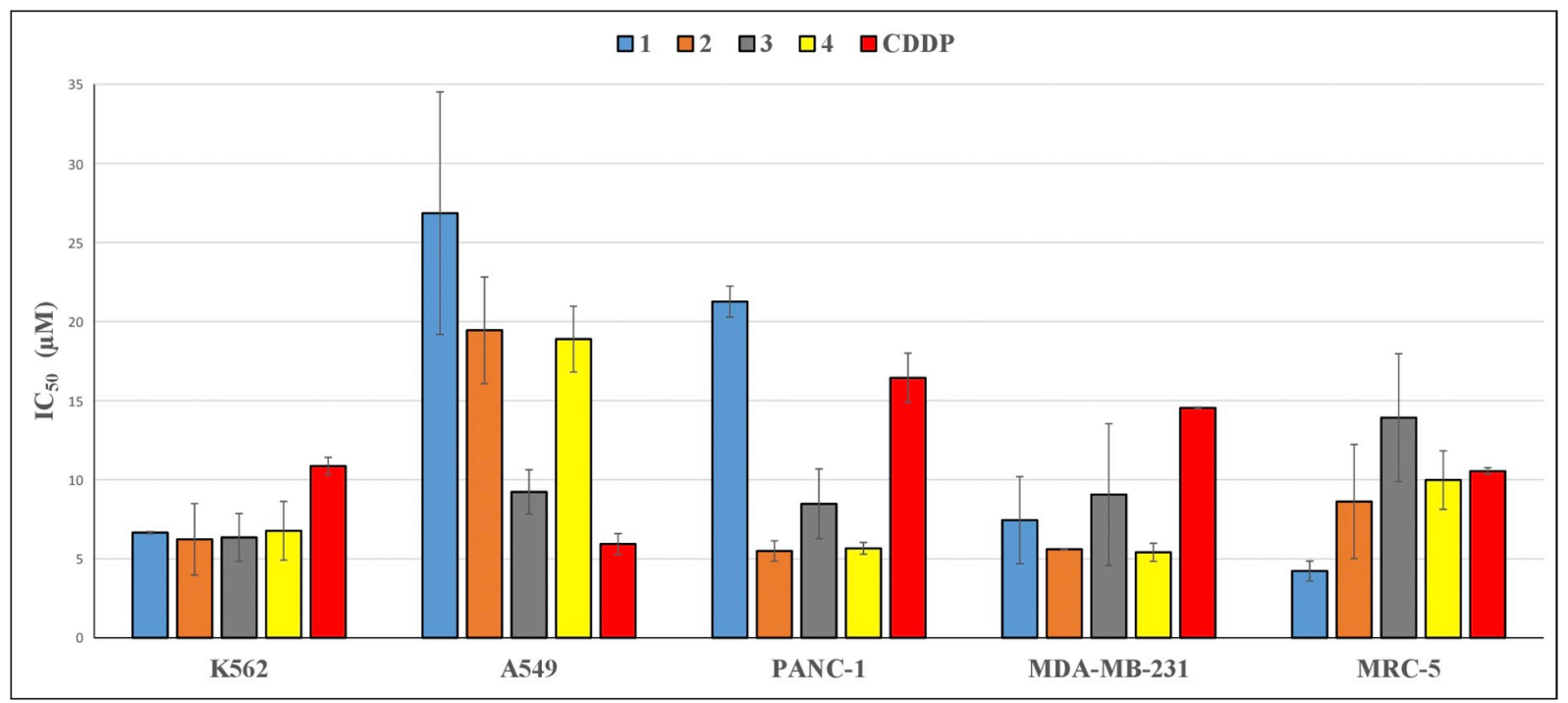

Fig. 3. Graphical representation of $\mathrm{IC}_{50}$ values $(\mu \mathrm{M})$ of the investigated ruthenium complexes and CDDP on a panel of cell lines; each $\mathrm{IC}_{50}$ value is the mean of two to three independent experiments with their corresponding standard deviation (SD). 
A)

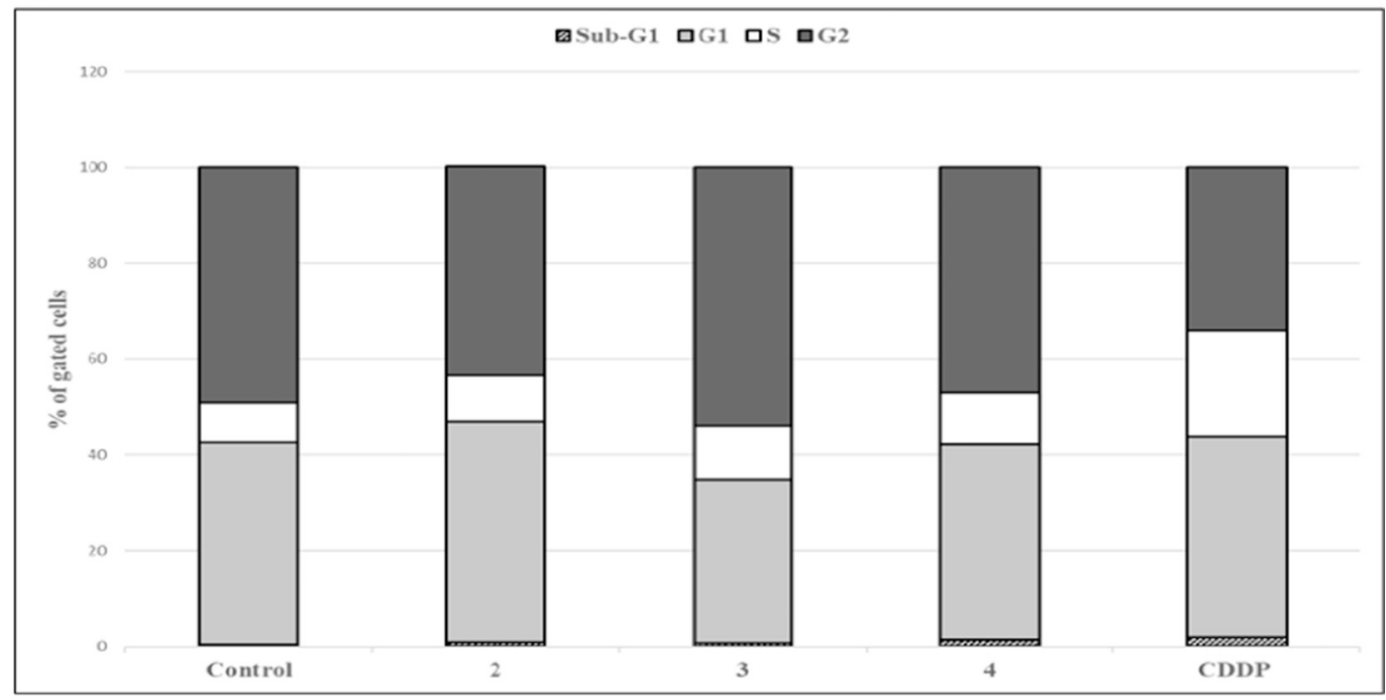

B)

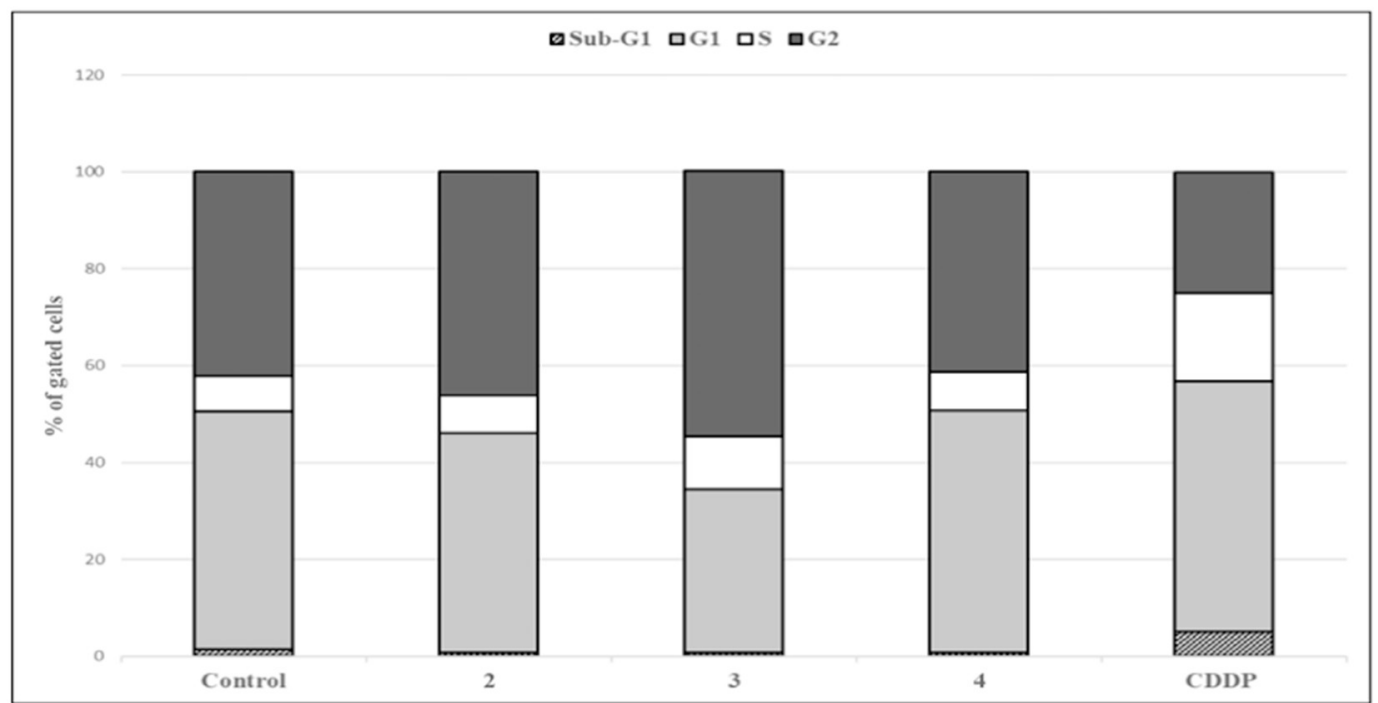

Fig. 4. Cell cycle phase distribution of PANC-1 cells, treated with complexes 2-4 or CDDP after A) $48 \mathrm{~h}$ and B) $72 \mathrm{~h}$. Bar graphs show representative experiments of at least three independent experiments.

cells) and DNA binding (0.2 ngPt/ $\mu g D N A)$, which is consistent to its poor cytotoxicity in PANC-1 cells, compared to ruthenium complexes 2-4. Still, despite that fact, CDDP action was demonstrated by induction of cell cycle arrest in the $S$ phase, and appearance of sub-G1 peak (Fig. 4). Knowing that only $5-10 \%$ of CDDP eventually form DNA-adducts in the cell, this allowed us to conclude that the poor CDDP-activity in PANC-1 cells is mainly due to the lower cellular uptake.

Our previous study of structurally related ruthenium complex $\left(\left[\left(\eta^{6}-\right.\right.\right.$ $p$-cymene) $\left.\left.\mathrm{Ru}\left(\mathrm{Me}_{2} \mathrm{dppz}\right) \mathrm{Cl}\right] \mathrm{PF}_{6}\right)$, showed its ability to accumulate in HeLa cells more efficiently than CDDP. Results of the present study in CDDP-resistant PANC-1 cells, clearly demonstrate significantly higher intracellular uptake of ruthenium complex 3 .

\subsection{Morphological analysis of cell death}

The morphological characteristics of cell death of PANC-1 cells induced with the investigated complexes and CDDP were analyzed by fluorescent microscopy and acridine orange/ethidium bromide dual staining [64]. After $48 \mathrm{~h}$ of treatment with $\mathrm{IC}_{50}$ concentrations, the cells started to lose their normal morphology and become rounded, in particular after treatment with complex $\mathbf{3}$ and CDDP (Supplementary Fig. SI1). In case of the other complexes ( 2 and 4 ), the majority of the cells were still with the morphology like the cells in the control, light green colored and elongated with an epithelial morphology. After $72 \mathrm{~h}$ of treatment, the number of cells was reduced compared to the control, again particularly after treatment with complex 3 and CDDP (Fig. 6).

The investigated complexes induced a similar effect on the morphology of cells, i.e. the cells become rounded. Some characteristics of apoptotic morphology are also present, like highly condensed chromatin that is uniformly fluorescent, in the crescents or spherical beads form around the periphery of the nucleus particularly after $72 \mathrm{~h}$ treatment. Other morphological characteristics of apoptosis are not present. The majority of cells are with preserved plasma membrane since cells incorporated only acridine orange (AO, green fluorescence). The morphological characteristics of secondary apoptosis and necrosis cells like orange to red colored chromatin, due to disrupted cell membrane in the individual cells are present.

Morphological criteria are often used to define the different types of 
A)

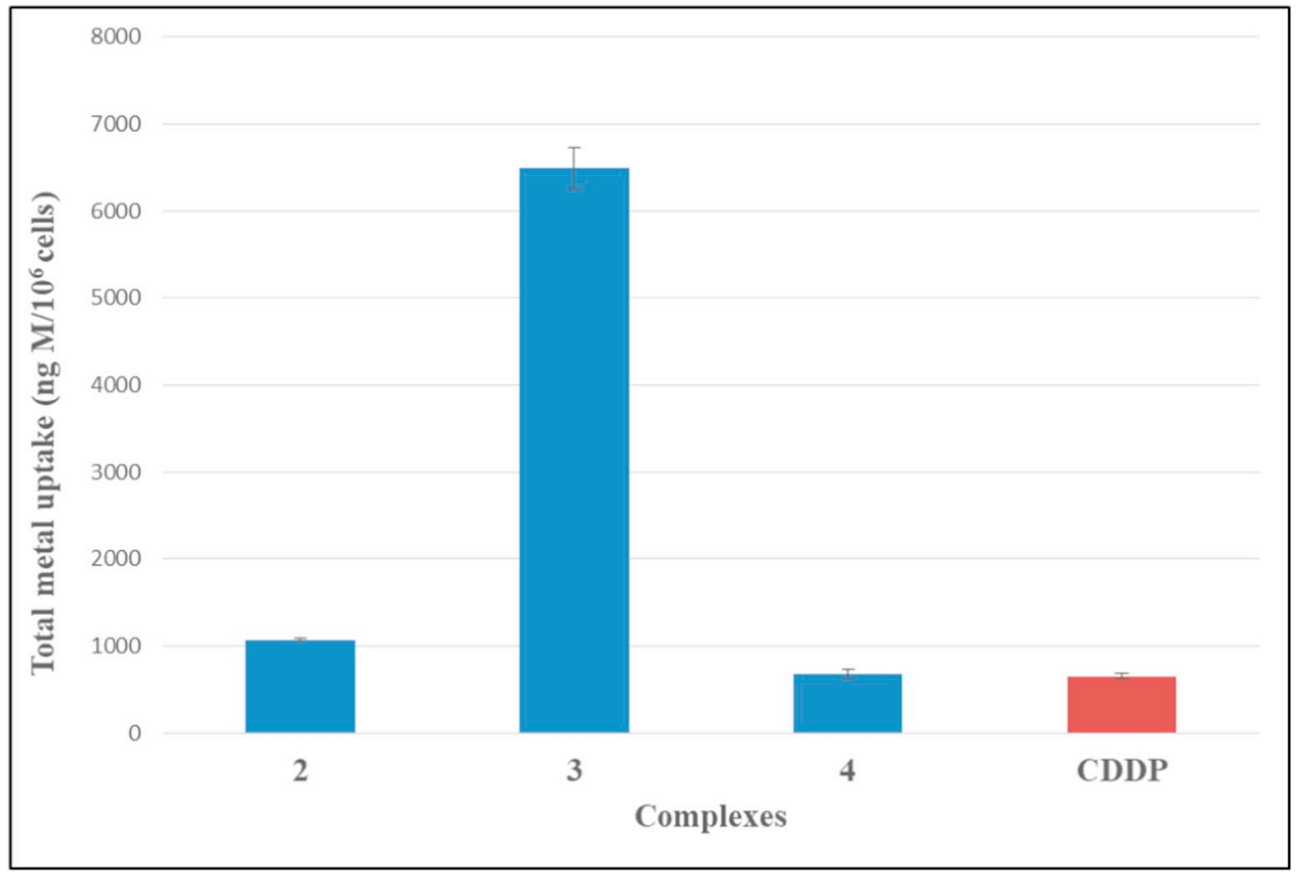

B)

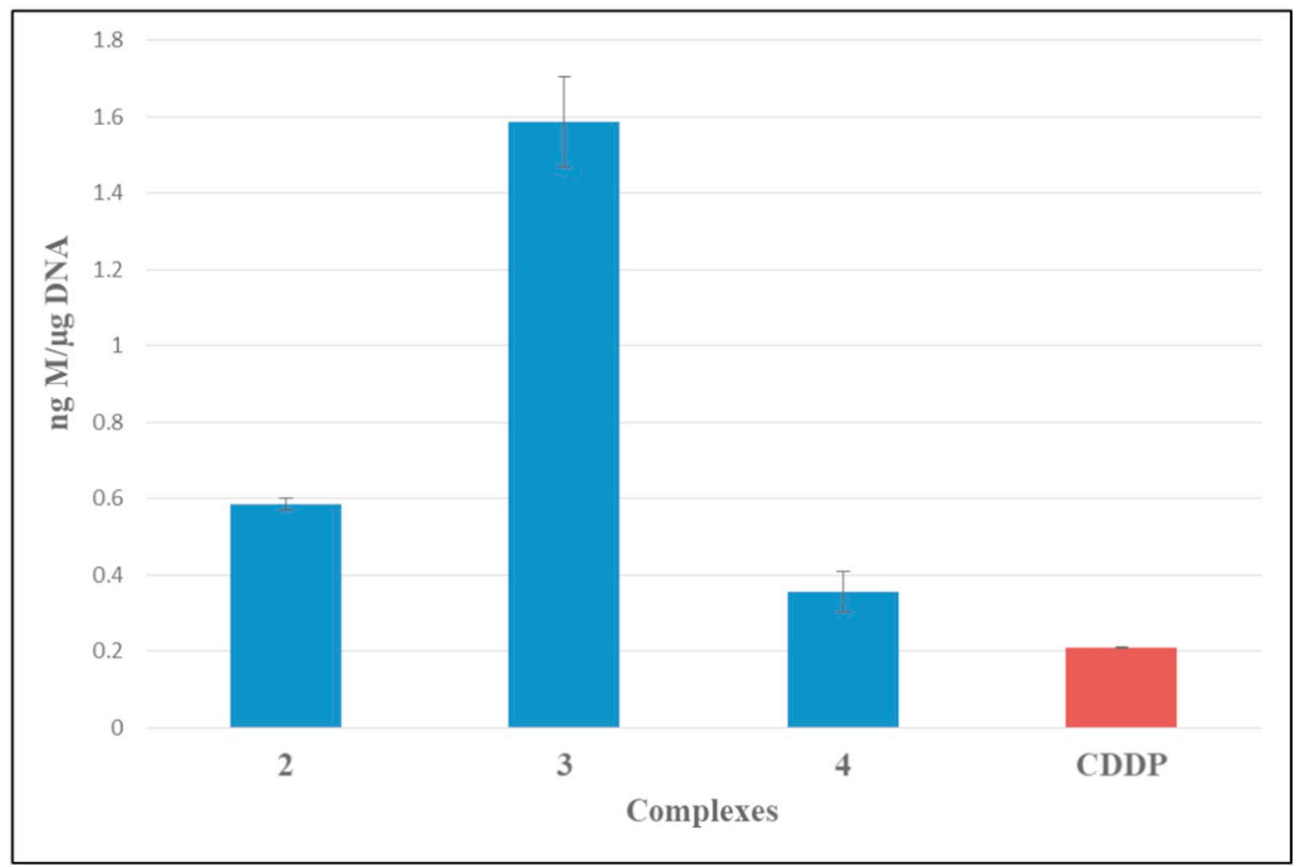

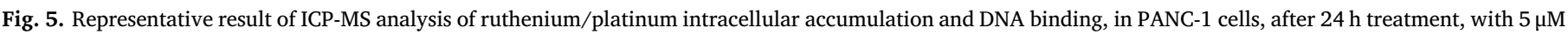

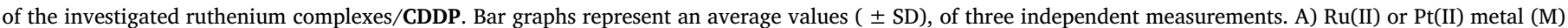
intracellular accumulation expressed as the ng M/10 $0^{6}$ cells; B) Ru(II) or Pt(II) metal (M) in cellular DNA, expressed as the ng M/ $\mu$ g DNA.

cell death [65]. According to morphological appearance, cell death can be classified to apoptotic, necrotic, autophagic or associated with mitosis. Moreover, it should be pointed out that the term 'apoptosis' hides a major degree of biochemical and functional heterogeneity [66]. Based on our results and having in mind morphological criteria for defining types of cell death, we cannot say for sure what type of cell death is induced by the investigated complexes, but we can emphasize that the integrity of the plasma membrane of the treated cells was preserved, some characteristics of apoptotic morphology are present and that there was no extensive necrosis.

4.6. Analysis of the efficacy of the investigated complexes in the $3 D$ MCTS model

Traditional research on the efficacy of anticancer drugs is usually performed in two-dimensional (2-D) cell cultures, which may not be a 

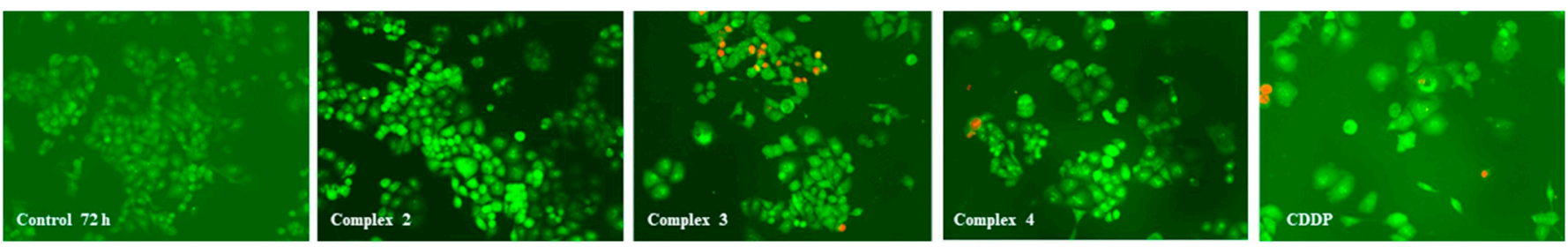

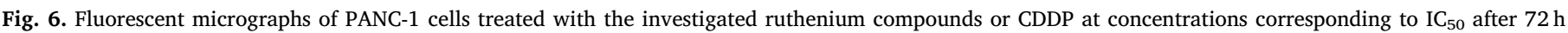
treatment. Untreated cells were used as control.
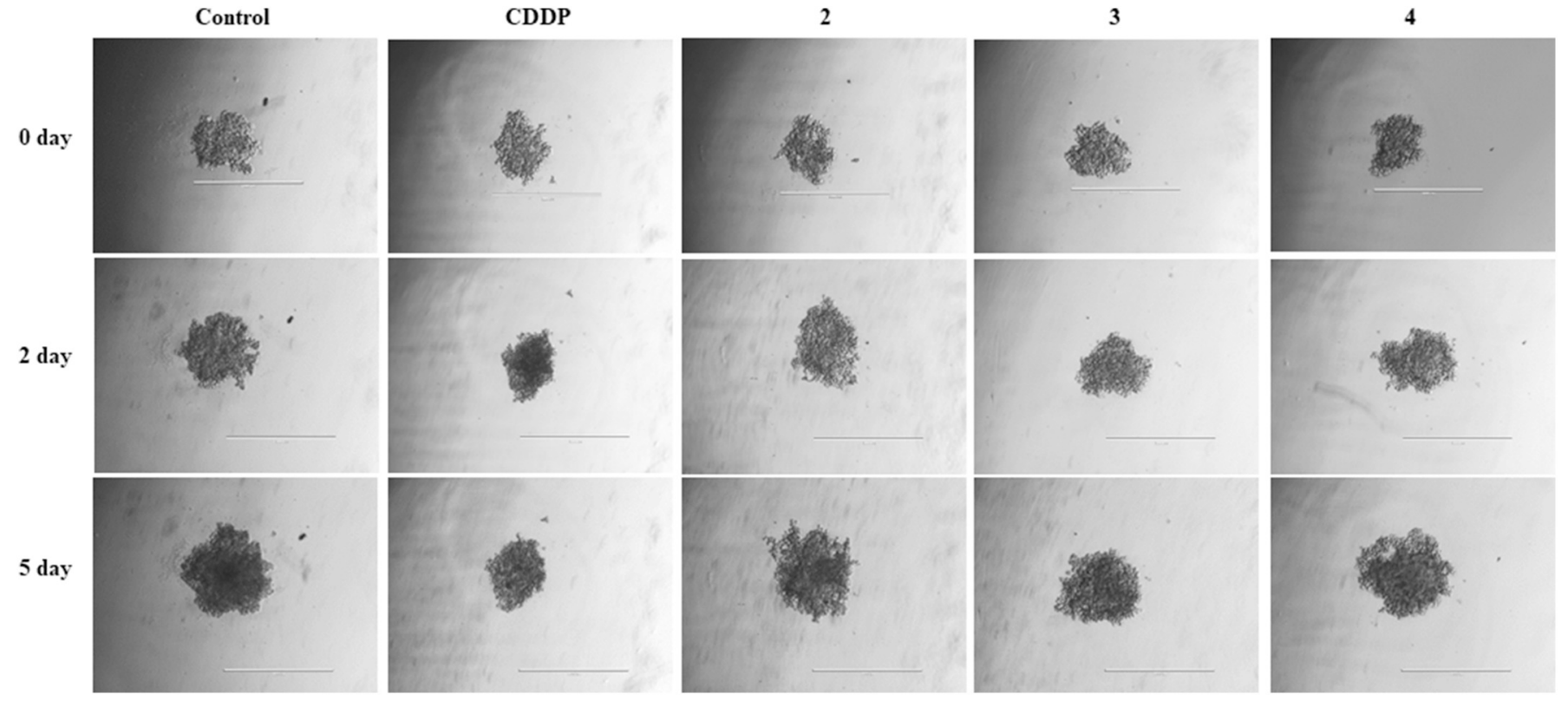

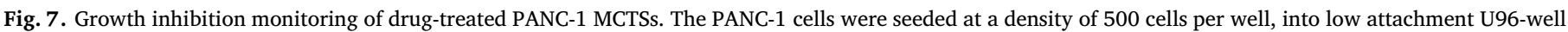

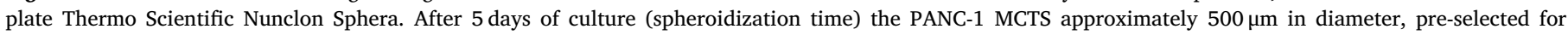

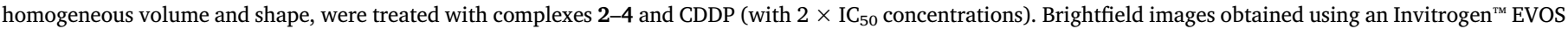
FLC ${ }^{\mathrm{TM}}$ imaging system. Scale bar: $1000 \mu \mathrm{m}$.

true indicator of the in vivo effectiveness of cancer treatments. Cells in a 3D culture environment differ morphologically and physiologically from the cells in a 2D culture environment. In the 3D cultures, the spatial organization of the cell surface receptors engaged in interactions with surrounding cells is achieved [66]. The physiological state of spheroids depends on the spheroid size, the individual and cell-typespecific behavior, the cell density, and also the culture time. In contrast to the 2D model systems where the cells are uniformly exposed to oxygen and nutrients, the cells in the 3D model systems are exposed to gradients of chemical and biological signals [67]. Hence, a 3D model, or multicellular tumor spheroids (MCTS) of PANC-1 cancer cells, was introduced in this research to investigate the efficacy of the reported ruthenium complexes on the growth kinetics of MCTSs over a period of time. We incubated the spheroids for 5 days either with CDDP or investigated ruthenium complexes (2-4). Unlike to their effect in a $2 \mathrm{D}$ cell culture, after treatment with complexes 2-4 there was no significant reduction in growth of PANC-1 cells MCTSs. The sizes of the PANC-1 MCTSs which were untreated (control) or treated with the investigated $\mathrm{Ru}(\mathrm{II})$ complexes $\left(2 \times \mathrm{IC}_{50}\right.$ concentrations) continuously increased with time (Fig. 7). In contrast, the MCTSs treated with CDDP $\left(2 \times \mathrm{IC}_{50}\right.$ concentration $\left.\sim 30 \mu \mathrm{M}\right)$ didn't change in size over time. Their growth is stopped, which becomes evident already after 2 days of treatment. Brightfield images (Fig. 7) show an increase in dark (dead) cells in the center of CDDP treated MCTS. These observations demonstrated that the investigated ruthenium complexes 2-4, although effectively inhibited cell proliferation and killed PANC-1 cancer cells in a 2D cell culture system, even more efficiently than CDDP according to
$\mathrm{IC}_{50}$ values (see Table 1), were not efficient in a 3D culture model as MCTSs continued to growth.

The live/dead viability analysis was performed as a two-color fluorescence staining using Calcein-AM and PI. The non-fluorescent cell-permeant Calcein-AM is converted into green fluorescent Calcein by intracellular esterases within living cells. In contrast, PI can only enter dead cells and emits red fluorescence upon binding to nucleic acids [42].

Further dual staining of MCTS with Calcein-AM and PI (Fig. 8 and Fig. 9) or with Thermo Fisher Live/Dead (Blue/Green) staining (Figure SI2) confirmed that most of the cells after treatment with the investigated ruthenium complexes were still alive. Complex 3 shows a slightly higher number of dead cells in MCTS of $500 \mu \mathrm{m}$ diameter, compared to the other two complexes. The spheroids compactness is apparently disturbed, since it appears that the structure of MCTS is distorted (especially around the perimeter) and spheroids gradually decay. While MCTS treated with CDDP totally disintegrated and staining confirmed majority of dead cell. It seems that the spheroid structure was sensitive to the mechanical disturbances caused by addition of dyes (Fig. 7 vs. Fig. 8 and Fig. 9, SI2). When working with MCTS we must consider that an important variable in MCTS is their size since it is correlated with cell function, as well as drug penetration and transport. The various spheroid sizes gives us different information. Smaller spheroids $(\sim 200 \mu \mathrm{m})$ are a good model system to recapitulate cell-cell and cell-matrix interactions but are not large enough to recapitulate oxygen gradients with hypoxic regions or proliferation gradients [68]. The spheroids between 200 and $500 \mu \mathrm{m}$ are generally 

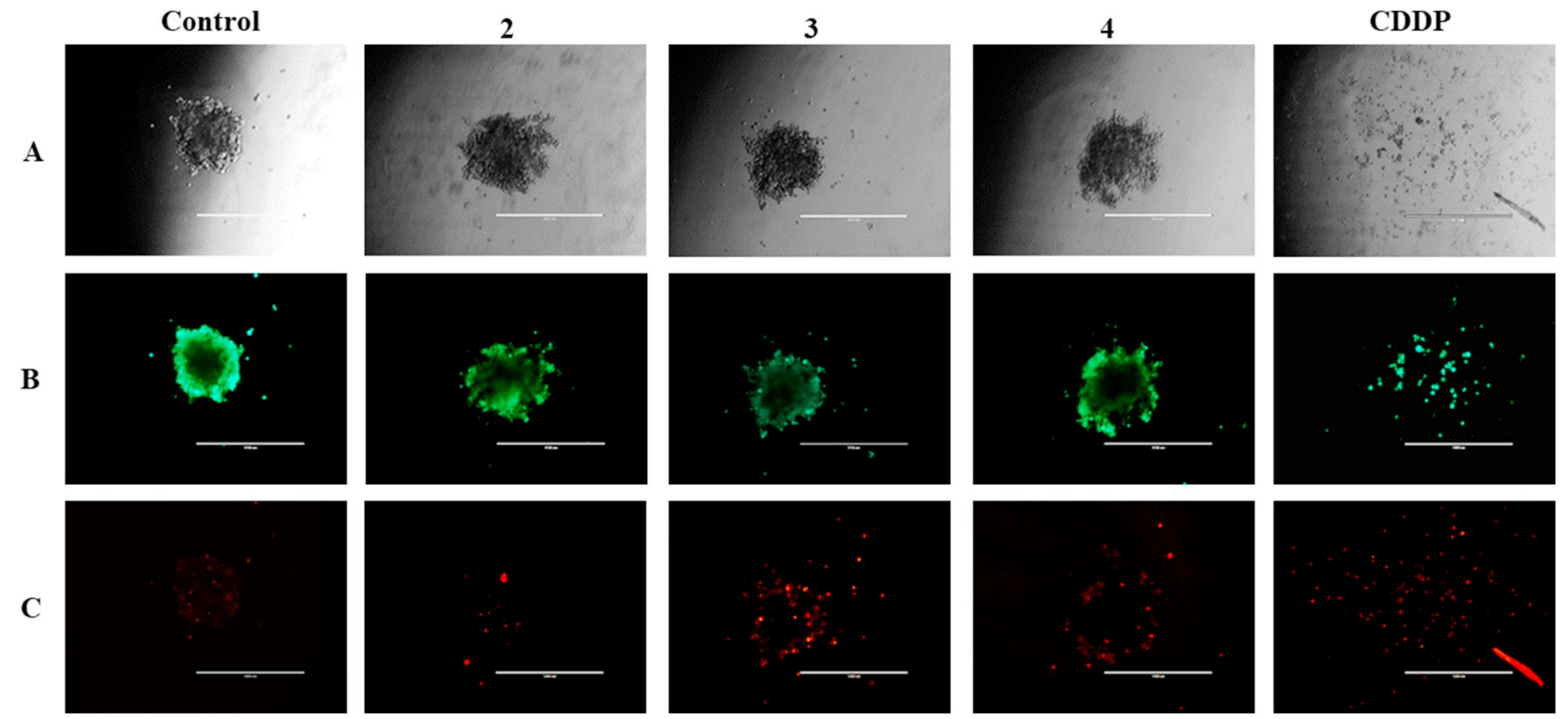

Fig. 8. Calcein-AM (green-live) and PI (red-dead) dual-staining on drug-treated PANC-1 cells MCTSs. The PANC-1 cells were seeded at a density of 500 cells per well, into low attachment U96-well plate Thermo Scientific Nunclon Sphera. After 5 days of culture (spheroidization time) the PANC-1 MCTS approximately $500 \mu \mathrm{m}$ in diameter, pre-selected for homogeneous volume and shape, were treated with complexes 1-3 and CDDP $\left(2 \times \mathrm{IC}_{50}\right.$ concentrations). Presented images were obtained using an Invitrogen ${ }^{\mathrm{TM}}$ EVOS FLC ${ }^{\mathrm{TM}}$ imaging system. A: bright field; B: Calcein-AM channel; C: PI channel. Scale bar: $1000 \mu \mathrm{m}$. (For interpretation of the references to colour in this figure legend, the reader is referred to the web version of this article.)

sufficiently large to develop gradients of oxygen, nutrients and catabolites [69]. Above a size of $400-600 \mu \mathrm{m}$, spheroids develop a central secondary necrosis where the innermost cells die of apoptosis or necrosis [68-70]. Larger spheroids generally have a viable cell rim that is $100-300 \mu \mathrm{m}$ thick around the necrotic core [70]. Therefore, in our research we treated MCTS with a diameter up to $500 \mu \mathrm{m}$ (Fig. 7, Fig. 8 and Fig. SI2) and with a diameter over $500 \mu \mathrm{m}$ (Fig. 9). Unfortunately, our results show that the investigated ruthenium complexes (2-4) were not efficient in the 3D culture model without distinction based on the size of MCTSs as only disintegration of the spheroids compactness is apparently observed in the spheroids rim in both cases.

A number of studies with DNA damaging drugs as well as with microtubuli interacting agents has shown that when tumor cells are grown as MCTS their sensitivity to anticancer chemotherapeutic drugs generally decreases [43-45,71].
A

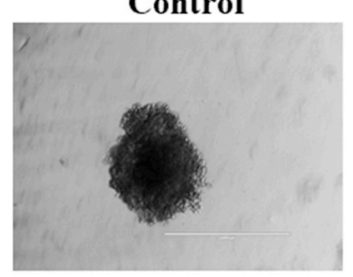

B

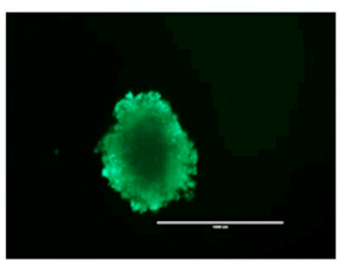

C

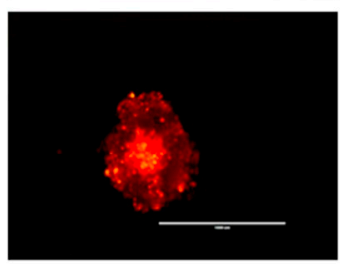

2
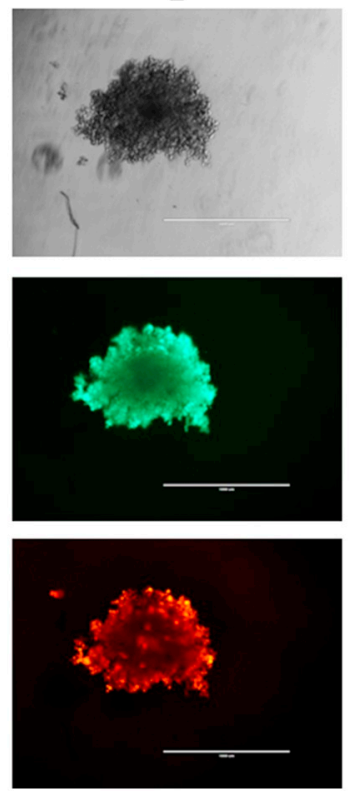

3
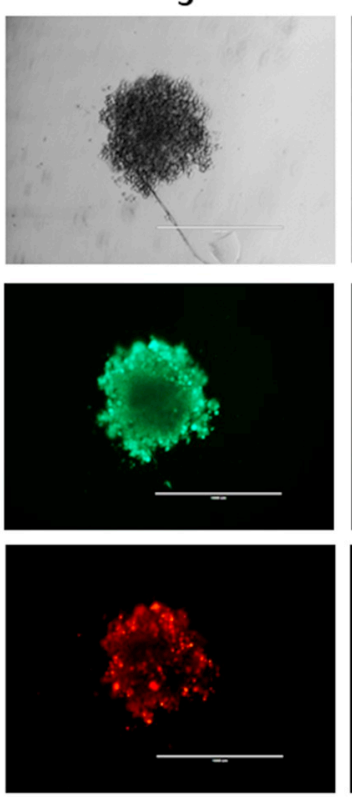

4
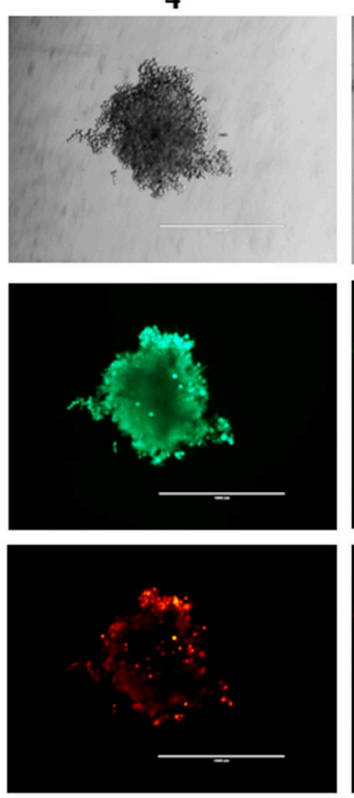

CDDP
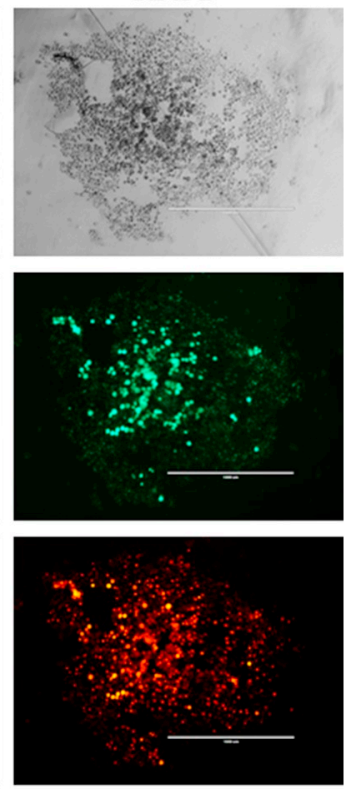

Fig. 9. Calcein-AM (green-live) and PI (red-dead) dual-staining on drug-treated PANC-1 cells MCTSs. The PANC-1 cells were seeded at a density of 1000 cells per well, into low attachment U96-well plate Thermo Scientific Nunclon Sphera (Nunclon Sphera 96 well U bottom plates). After 5 days of culture (spheroidization time) the PANC-1 MCTS aggregates diameter over $500 \mu \mathrm{m}$ pre-selected for homogeneous volume and shape were treated with complexes 2-4 and CDDP (2xIC 50 concentrations). Presented images were obtained using an Invitrogen ${ }^{\mathrm{TM}}$ EVOS FLC $^{\mathrm{TM}}$ imaging system. A: bright field; B: Calcein-AM channel; C: PI channel Scale bar: $1000 \mu \mathrm{m}$. (For interpretation of the references to colour in this figure legend, the reader is referred to the web version of this article.) 


\section{Conclusion}

The previous study of the mechanism of action of half-sandwich Ru (II)-arene complexes of the type $\left[\left(\eta^{6}-p\right.\right.$-cymene $\left.) \mathrm{Ru}\left(\mathrm{Me}_{2} \mathrm{dppz}\right) \mathrm{Cl}\right] \mathrm{PF}_{6}$, has revealed that this compound acts as strong cytotoxic agent, due to an efficient cellular accumulation and its ability to reach and bind nuclear DNA with a much higher affinity than CDDP [42]. Based on these studies, we synthesized a class of novel Ru complexes containing 1,10-phenantroline derivatives to study their structure-activities relationship and reveal the changes in biological activity resulting from small structural modifications of the four Ru(II) complexes. The results of the screening of cell growth inhibitory action in a 2D model system, on the panel of cancer cell lines, indicated the high activity, even higher than $\mathrm{CDDP}$, with $\mathrm{IC}_{50}$ values ranging from 5 to $9 \mu \mathrm{M}$ in CDDP resistant cell lines PANC-1 and MDA-MB-231. Based on the $\mathrm{IC}_{50}$ values, we can state that minor changes in dppz ligand, like the introduction of a strongly electron-withdrawing group $-\mathrm{NO}_{2}$ (4) or a weakly electronwithdrawing group $-\mathrm{Cl}$ group (3) were not sufficient to induce important changes in the biological activity, compared to complexes without substituents on the dppz ligand (2). As complexes 2-4 had significantly high growth inhibitory activity in PANC-1 and MDA-MB231 cells, further investigation of the mechanism of action was necessarily. Studies in a 3D cell culture of multicellular tumor spheroids (MCTS) of PANC-1 cells showed no significant retardation or reduction in growth, after treatment with the investigated ruthenium complexes. Disintegration of the spheroids compactness is observed only in the spheroids rim and majority of the cells is found alive, in contrast to CDDP treatment, which induced retardation in MCTS growth. MCTS treated with CDDP, disintegrated after adding stains, and staining confirmed the majority of dead cells. Having in mind the complexity of a 3D model system and our results further investigations in this model system are needed, varying time and concentrations, as well as experimental conditions, for more accurate understanding of the effect of the investigated complexes. ICP-MS analysis in PANC-1 cells, revealed surprisingly more efficient cellular uptake of complex 3 compared to complexes 2, 4 and CDDP. The DNA binding followed the same trend, meaning that concentration of complexes that reached cellular DNA, decreased in the following order: $3>2>4<$ CDDP. Still, ICP-MS results did not show clear correlation to the cytotoxic activity of complexes in the present study, as cytotoxicity decreased as following: $2>4>3>$ CDDP. We may conclude that higher intracellular accumulation of ruthenium complexes 2-4, comparing to CDDP and higher DNA binding, perhaps by intercalation, certainly contributed to their activity in PANC-1 cells. Additionally, action of 2-4 was devoid of notable cell cycle perturbations. Only complex 3 caused minor cell cycle arrest, characterized by accumulation of cells in the G2-M phase (52.09\% vs control $42.01 \%)$. Absence of the Sub-G1 peak in cell cycle analysis indicates that there was no fragmentation of DNA. This is a completely different effect of that observed with CDDP, which induced accumulation of cells in the $S$ phase and increase of Sub-G1 peak. Taken together, this study provides important information for further development and investigation of $\mathrm{Ru}(\mathrm{II})$-arene complexes with dipyridophenazine type ligands, as anticancer agents.

\section{Declaration of competing interest}

The authors declare that they have no known competing financial interests or personal relationships that could have appeared to influence the work reported in this paper.

\section{Acknowledgments}

A.S., R.V.D. and K.V.H. thank the Erasmus Mundus Basileus V project. K.V.H. and R.V.D. thank the Hercules Foundation (project AUGE/11/029 "3D-SPACE: 3D Structural Platform Aiming for Chemical Excellence") for funding. K.V.H. thanks the Special Research Fund
(BOF) - UGent (project 01N03217) for funding. This work was supported by the Ministry of Education, Science and Technological Development of the Republic of Serbia, grant numbers 172035 and III 41026. The authors thank to Dr. Miodrag Guzvic (Research Associate, Chair of Experimental Medicine and Therapy Research Faculty of Medicine University of Regensburg, Germany) for kindly providing of PANC-1 cell line.

\section{Appendix A. Supplementary data}

Supplementary data to this article can be found online at https:// doi.org/10.1016/j.jinorgbio.2019.110869.

\section{References}

[1] B. Rosenberg, L. Van Camp, T. Krigas, Inhibition of cell division in Escherichia coli by electrolysis products from a platinum electrode, Nature 205 (1965) 698-699, https://doi.org/10.1038/205698a0.

[2] F.M. Muggia, A. Bonetti, J.D. Hoeschele, M. Rozencweig, S.B. Howell, Platinum antitumor complexes: 50 years since Barnett Rosenberg's discovery, J. Clin. Oncol 33 (2015) 4219-4226, https://doi.org/10.1200/JCO.2015.60.7481.

[3] L. Kelland, The resurgence of platinum-based cancer chemotherapy, Nat. Rev. Cancer 7 (2007) 573-584, https://doi.org/10.1038/nrc2167.

[4] P. Perego, J. Robert, Oxaliplatin in the era of personalized medicine: from mechanistic studies to clinical efficacy, Cancer Chemother. Pharmacol. 77 (2016) 5-18, https://doi.org/10.1007/s00280-015-2901-x.

[5] S. Manic, L. Gatti, N. Carenini, G. Fumagalli, F. Zunino, P. Perego, Mechanisms controlling sensitivity to platinum complexes: role of p53 and DNA mismatch repair, Curr. Cancer Drug Targets 3 (1) (2003) 21-29, https://doi.org/10.2174/ 1568009033333727.

[6] L. Gatti, G. Cassinelli, N. Zaffaroni, C. Lanzi, P. Perego, New mechanisms for old drugs: insights into DNA-unrelated effects of platinum compounds and drug resistance determinants, Drug Resist. Updat. 20 (2015) 1-11, https://doi.org/10. 1016/j.drup.2015.04.001.

[7] C.S. Allardyce, P.J. Dyson, Ruthenium in medicine: current clinical uses and future prospects, Platinum Metals Rev 45 (2) (2001) 62-69.

[8] E. Alessio, G. Mestroni, A. Bergamo, G. Sava, Ruthenium antimetastatic agents, Curr. Top. Med. Chem. 4 (2004) 1525-1535, https://doi.org/10.2174/ 1568026043387421.

[9] A. Levina, A. Mitra, P.A. Lay, Recent developments in ruthenium anticancer drugs, Metallomics 1 (2009) 458-470, https://doi.org/10.1039/b904071d.

[10] G.S. Fink, Arene ruthenium complexes as anticancer agents, Dalton Trans. 39 (2010) 1673-1688, https://doi.org/10.1039/B916860P.

[11] I. Kostova, Ruthenium complexes as anticancer agents, Curr. Med. Chem. 13 (2006) 1085-1107, https://doi.org/10.2174/092986706776360941.

[12] S. Emmanuel, A.E. Antonarakis, Ruthenium-based chemotherapeutics: are they ready for prime time? Cancer Chemother. Pharmacol. 66 (2010) 1-9, https://doi. org /10.1007/s00280-010-1293-1.

[13] I. Romero-Canelón, P.J. Sadler, Next-generation metal anticancer complexes: multitargeting via redox modulation, Inorg. Chem. 52 (2013) 12276-12291, https:// doi.org/10.1021/ic400835n.

[14] S. Denise de Oliveira, Perspectives for novel mixed diruthenium-organic drugs as metallopharmaceuticals in cancer therapy, Anti Cancer Agents Med. Chem. 10 (2010) 312-323, https://doi.org/10.2174/187152010791162333.

[15] C. Mari, V. Pierroz, S. Ferrari, G. Gasser, Combination of Ru(II) complexes and light: new frontiers in cancer therapy, Chem. Sci. 6 (2015) 2660-2686, https://doi.org/ 10.1039/c4sc03759f.

[16] K.K. Jovanović, M. Tanić, I. Ivanović, N. Gligorijević, B.P. Dojčinović, S. Radulović, Cell cycle, apoptosis, cellular uptake and whole-transcriptome microarray gene expression analysis of HeLa cells treated with a ruthenium(II)-arene complex with an isoquinoline-3-carboxylic acid ligand, J. Inorg. Biochem. 163 (2016) 362-373, https://doi.org/10.1016/j.jinorgbio.2016.04.011.

[17] A. Tadić, J. Poljarević, M. Krstić, M. Kajzerberger, S. Aranđelović, S. Radulović, C. Kakoulidou, A.N. Papadopoulos, G. Psomas, S. Grgurić-Šipka, Ruthenium-arene complexes with NSAIDs: synthesis, characterization and bioactivity, New J. Chem 42 (2018) 3001-3019, https://doi.org/10.1039/C7NJ04416J.

[18] C. Gaiddon, M. Pfeffer, The fate of cycloruthenated compounds: from C-H activation to innovative anticancer therapy, Eur. J. Inorg. Chem. 2017 (2017) 1-17, https://doi.org/10.1002/ejic.201601216.

[19] E. Alessio, Thirty years of the drug candidate NAMI-A and the myths in the field of ruthenium anticancer compounds: a personal perspective, Eur. J. Inorg. Chem. (2017) 1549-1560, https://doi.org/10.1002/ejic.201600986.

[20] L.M. Wilhelmsson, F. Westerlund, P. Lincoln, B. Nordén, DNA-binding of semirigid binuclear ruthenium complex $\Delta, \Delta$-[ $\left[\mu-\left(11,11^{\prime} \text {-bidppz }\right)(\text { phen })_{4} \mathrm{Ru}_{2}\right]^{4+}$ : extremely slow intercalation kinetics, J. Am. Chem. Soc. 124 (2002) 12092, , https://doi.org/ 10.1021/ja027252f.

[21] G.E. Atilla-Gokcumen, N. Pagano, C. Streu, J. Maksimoska, P. Filippakopoulos, S. Knapp, E. Meggers, Extremely tight binding of a ruthenium complex to glycogen synthase kinase 3, ChemBioChem 9 (2008) 2933-2936, https://doi.org/10.1002/ cbic. 200800489.

[22] J.F. Kou, C. Qian, J.Q. Wang, X. Chen, L.L. Wang, H. Chao, L.N. Ji, Chiral ruthenium (II) anthraquinone complexes as dual inhibitors of topoisomerases I and II, J. Biol. Inorg. Chem. 17 (2012) 81-96, https://doi.org/10.1007/s00775-011-0831-6.

[23] S. Chatterjee, S. Kundu, A. Bhattacharyya, C. Hartinger, P. Dyson, The ruthenium (II)-arene compound RAPTA-C induces apoptosis in EAC cells through 
mitochondrial and p53-JNK pathways, J. Biol. Inorg. Chem. 13 (2008) 1149-1155, https://doi.org/10.1007/s00775-008-0400-9.

[24] S.H. Lai, G.B. Jiang, J.H. Yao, W. Li, B.J. Han, C. Zhang, C.C. Zeng, Y.J. Liu, Cytotoxic activity, DNA damage, cellular uptake, apoptosis and western blot analysis of ruthenium(II) polypyridyl complex against human lung decarcinoma A549 cell, J. Inorg. Biochem. 152 (2015) 1-9, https://doi.org/10.1016/j.jinorgbio.2015. 08.012 .

[25] H.A. Burris, S. Bakewell, J.C. Bendell, J. Infante, S.F. Jones, D.R. Spigel, G.J. Weiss, R.K. Ramanathan, A. Ogden, D. Von Hoff, ESMO Open 1 (6) (2017) e000154, https://doi.org/10.1136/esmoopen-2016-000154.

[26] J. Hess, H.H. Adrian Kaiser, V. Pierroz, O. Blacque, H. Chao, G. Gasser, Evaluation of the medicinal potential of two ruthenium(II) polypyridine complexes as one- and two-photon photodynamic therapy photosensitizers, Chemistry a European Journal 23 (2017) 9888-9896, https://doi.org/10.1002/chem.201701392.

[27] C. Mari, V. Pierroz, R. Rubbiani, M. Patra, J. Hess, B. Spingler, L. Oehninger, J. Schur, I. Ott, L. Salassa, S. Ferrari, G. Gasser, DNA intercalating $\mathrm{Ru}^{\mathrm{II}}$ polypyridyl complexes as effective photosensitizers in photodynamic therapy, Chem. Eur. J. 20 (2014) 14421-14436, https://doi.org/10.1002/chem.201402796.

[28] J. Fong, K. Kasimova, Y. Arenas, P. Kaspler, S. Lazic, A. Mandel, L. Lilge, A novel class of ruthenium-based photosensitizers effectively kills in vitro cancer cells and in vivo tumors, Photochem. Photobiol. Sci. 14 (2015) 2014-2023, https://doi.org/10. 1039/C4PP00438H.

[29] H.Y. Huang, P.Y. Zhang, B.L. Yu, Y.J. Chen, Q. Wang, L.N. Ji, H. Chao, Targeting nucleus DNA with a cyclometalated dipyridophenazineruthenium(II) complex, J. Med. Chem. 57 (2014) 8971-8983, https://doi.org/10.1021/jm501095r.

[30] C. Zhang, C.C. Zeng, S.H. Lai, D.G. Xing, W. Li, B.J. Han, Y.J. Liu, Synthesis, cytotoxicity in vitro, apoptosis, cell cycle arrest and comet assay of asymmetry ruthenium(II) complexes, Polyhedron 106 (2016) 115-124, https://doi.org/10.1016/ j.poly.2015.12.058.

[31] V. Pierroz, T. Joshi, A. Leonidova, C. Mari, J. Schur, I. Ott, L. Spiccia, S. Ferrari, G. Gasser, Molecular and cellular characterization of the biological effects of ruthenium(II) complexes incorporating 2-pyridyl-2-pyrimidine-4-carboxylic acid, J. Am. Chem. Soc. 134 (2012) 20376-20387, https://doi.org/10.1021/ja307288s.

[32] U. Schatzschneider, J. Niesel, I. Ott, R. Gust, H. Alborzinia, S. Wölfl, Cellular uptake, cytotoxicity, and metabolic profiling of human cancer cells treated with ruthenium(II) polypyridyl complexes [Ru(bpy) $2(\mathrm{~N}-\mathrm{N})] \mathrm{Cl}_{2}$ with $\mathrm{N}-\mathrm{N}=$ bpy, phen, dpq, dppz, and dppn, ChemMedChem 3 (2008) 1104-1109, https://doi.org/10.1002/ cmdc. 200800039.

[33] M.V. Babak, S.M. Meier, A.A. Legin, M.S. Adib Razavi, A. Roller, M.A. Jakupec, B.K. Keppler, C.G. Hartinger, Half-sandwich ruthenium(II) biotin conjugates as biological vectors to cancer cells, Chem. Eur. J. 19 (2013) 4308-4318, https://doi. org/10.1002/chem.201403974.

[34] W. Kandioller, A. Kurzwernhart, M. Hanif, S.M. Meier, H. Henke, B.K. Keppler, C.G. Hartinger, Pyrone derivatives and metals: from natural products to metalbased drugs, J. Organomet. Chem. 696 (2011) 999-1010, https://doi.org/10.1016/ j.jorganchem.2010.11.010.

[35] J.H. Kasser, W. Kandioller, C.G. Hartinger, A.A. Nazarov, V.B. Arion, P.J. Dyson, B.K. Keppler, Mannich products of kojic acid and N-heterocycles and their Ru (II)-arene complexes: synthesis, characterization and stability, J. Organomet. Chem. 695 (2010) 875-881, https://doi.org/10.1016/j.jorganchem.2010.01.007.

[36] F.A. Khan, B. Therrien, G. Süss-Fink, O. Zava, P.J. Dyson, Arene ruthenium dichloro complexes containing isonicotinic ester ligands: synthesis, molecular structure and cytotoxicity, J. Organomet. Chem. 730 (2013) 49-56, https://doi.org/10.1016/j. jorganchem.2012.10.016.

[37] A.F.A. Peacock, P.J. Sadler, Medicinal organometallic chemistry: designing metal arene complexes as anticancer agents, Chem. Asian J. 3 (2008) 1890-1899, https:// doi.org/10.1002/asia.200800149.

[38] Z. Wen, Q. Liao, Y. Hu, L. You, L. Zhou, Y. Zhao, A spheroid-based 3-D culture model for pancreatic cancer drug testing, using the acid phosphatase assay, Braz. J. Med. Biol. Res. 46 (2013) 634-642, https://doi.org/10.1590/1414-431X20132647.

[39] H. Huang, P. Zhang, Y. Chen, L. Ji, H. Chao, Labile ruthenium(II) complexes with extended phenyl-substituted terpyridyl ligands: synthesis, aquation and anticancer evaluation, Dalton Trans. 44 (2015) 15602-15610, https://doi.org/10.1039/ C5DT02446C.

[40] A.I. Minchinton, I.F. Tannock, Drug penetration in solid tumours, Nat. Rev. Cancer 6 (2006) 583-592, https://doi.org/10.1038/nrc1893.

[41] E.C. Costa, et al., 3D tumor spheroids: an overview on the tools and techniques used for their analysis, Biotechnol. Adv. 34 (2016) 1427-1441, https://doi.org/10.1016/ j.biotechadv.2016.11.002.

[42] S. Nikolić, L. Rangasamy, N. Gligorijević, S. Aranđelović, S. Radulović, G. Gasser, S. Grgurić-Šipka, Synthesis, characterization and biological evaluation of novel Ru (II)-arene complexes containing intercalating ligands, J. Inorg. Biochem. 160 (2016) 156-165, https://doi.org/10.1016/j.jinorgbio.2016.01.005.

[43] A. Sivaraman, J.K. Leach, S. Townsend, T. Iida, B.J. Hogan, D.B. Stolz, R. Fry, L.D. Samson, S.R. Tannenbaum, L.G. Griffith, A microscale in vitro physiological model of the liver: predictive screens for drug metabolism and enzyme induction, Curr. Drug Metab. 6 (2005) 569-591, https://doi.org/10.2174/ 138920005774832632.

[44] J. Friedrich, R. Ebner, L.A. Kunz-Schughart, Experimental anti-tumor therapy in 3D: spheroids-old hat or new challenge? Int. J. Radiat. Biol. 83 (2007) 849-871, https://doi.org/10.1080/09553000701727531.

[45] C. Fischbach, R. Chen, T. Matsumoto, T. Schmelzle, J.S. Brugge, P.J. Polverini, D.J. Mooney, Engineering tumors with 3D scaffolds, Nat. Methods 4 (2007) 855-860, https://doi.org/10.1038/nmeth1085.

[46] R.H. Zheng, H.C. Guo, H.J. Jiang, K.H. Xu, B.B. Liu, W.L. Sun, Z.Q. Shen, A new and convenient synthesis of phendiones oxidated by $\mathrm{KBrO}_{3} / \mathrm{H}_{2} \mathrm{SO}_{4}$ at room temperature, Chinese Chem. Lett. 21 (2010) 1270-1272, https://doi.org/10.1016/ j.cclet 2010.05.030.

[47] C.M. Dupureur, J.K. Barton, Structural studies of $\Lambda$ - and $\Delta$-[Ru(phen) $\left.)_{2} \mathrm{dppz}\right]^{2+}$ bound to $\mathrm{d}(\mathrm{GTCGAC})_{2}$ : characterization of enantioselective intercalation, Inorg. Chem. 36 (1997) 33-43, https://doi.org/10.1021/ic960738a.

[48] P. Aguirre, R. López, D. Villagra, I. Azocar-Guzman, A.J. Pardey, S.A. Moya, Synthesis of ruthenium complexes with carbonyl and polypyridyl ligands derived from dipyrido[3,2-a:2', $3^{\prime}$-c]phenazine: application to the water gas shift reaction, Appl. Organometal. Chem. 17 (2003) 36-41, https://doi.org/10.1002/aoc.385.

[49] Rigaku Oxford Diffraction (2015). CrysAlis Pro; Rigaku Oxford Diffraction, Yarnton, England.

[50] O.V. Dolomanov, L.J. Bourhis, R.J. Gildea, J.A.K. Howard, H. Puschmann, OLEX2: a complete structure solution, refinement and analysis program, J. Appl. Crystallogr. 42 (2009) 339-341, https://doi.org/10.1107/S0021889808042726.

[51] G.M. Sheldrick, A short history of SHELX, Acta Crystallogr. Sect. A 64 (2008) 112-122, https://doi.org/10.1107/S0108767307043930.

[52] G.M. Sheldrick, Crystal structure refinement with SHELXL, Acta Crystallogr. Sect. C 71 (2015) 3-8, https://doi.org/10.1107/S2053229614024218.

[53] R. Supino, Methods in molecular biology, in: S. O'Hare, C.K. Atterwill (Eds.), In Vitro Toxicity Testing Protocols, Humana Press, New Jersey, 1995, pp. 137-149.

[54] M.G. Ormerod, Analysis of DNA-general methods, in: M.G. Ormerod (Ed.), Flow Cytometry, a Practical Approach, Oxford University Press, New York, 1994, pp. $119-125$.

[55] K.K. Jovanović, N. Gligorijević, R. Gaur, L. Mishra, S. Radulović, Anticancer activity of two ruthenium(II)-DMSO-chalcone complexes: comparison of cytotoxic, proapoptotic and antimetastatic potential, JBUON 21 (2016) 482-490.

[56] A. Savić, L. Filipović, S. Aranđelović, B. Dojčinović, S. Radulović, T.J. Sabo, S. Grgurić-Šipka, Synthesis, characterization and cytotoxic activity of novel platinum(II) iodido complexes, Eur. J. Med. Chem. 82 (2014) 372-384, https://doi org /10.1016/j. ejmech.2014.05.060.

[57] M.M. Milutinović, A. Rilak, I. Bratsos, O. Klisurić, M. Vraneš, N. Gligorijević, S. Radulović, Ž.D. Bugarčić, New 4'-(4-chlorophenyl)-2,2':6',2"-terpyridine ruthenium(II) complexes: synthesis, characterization, interaction with DNA/BSA and cytotoxicity studies, J. Inorg. Biochem. 169 (2017) 1-12, https://doi.org/10.1016/ j.jinorgbio.2016.10.001.

[58] S. Nikolić, D.M. Opsenica, V. Filipović, B. Dojčinović, S. Aranđelović, S. Radulović, S. Grgurić-Šipka, Strong in vitro cytotoxic potential of new ruthenium-cymene complexes, Organometallics 34 (2015) 3464-3473, https://doi.org/10.1021/acs. organomet.5b00041.

[59] B.J. Pages, D.L. Ang, E.P. Wright, J.R. Aldrich-Wright, Metal complex interactions with DNA, DaltonTrans 44 (2015) 3505-3526, https://doi.org/10.1039/ C4DT02700K.

[60] G. Li, L. Sun, L. Ji, H. Chao, Ruthenium(II) complexes with dppz: from molecular photoswitch to biological applications, Dalton Trans. 45 (2016) 13261-13276, https://doi.org/10.1039/C6DT01624C.

[61] E.L. Deer, J. González-Hernández, J.D. Coursen, J.E. Shea, J. Ngatia, C.L. Scaife, M.A. Firpo, S.J. Mulvihill, Phenotype and genotype of pancreatic cancer cell lines, Pancreas 39 (2010) 425-435, https://doi.org/10.1097/MPA.0b013e3181c15963.

[62] A.E. Eggera, C. Rappela, M.A. Jakupec, C.G. Hartingera, P. Heffeterb, B.K. Keppler, Development of an experimental protocol for uptake studies of metal compounds in adherent tumor cells, J. Anal. At. Spectrom. 24 (2009) 51-61, https://doi.org/10. 1039/B810481F.

[63] M.A. Fuertes, C. Alonso, J.M. Perez, Biochemical modulation of cisplatin mechanisms of action: enhancement of antitumor activity and circumvention of drug resistance, Chem. Rev. 103 (2003) 645-662, https://doi.org/10.1021/cr020010d.

[64] K. Liu, P.C. Liu, R. Liu, X. Wu, Dual AO/EB staining to detect apoptosis in osteosarcoma cells compared with flow cytometry, Med. Sci. Monit. Basic Res. 21 (2015) 15-20, https://doi.org/10.12659/MSMBR.893327.

[65] G. Kroemer, L. Galluzzi, P. Vandenabeele, J. Abrams, E.S. Alnemri, E.H. Baehrecke, M.V. Blagosklonny, W.S. El-Deiry, P. Golstein, D.R. Green, M. Hengartner, R.A. Knight, S. Kumar, S.A. Lipton, W. Malorni, G. Nuñez, M.E. Peter, J. Tschopp, J. Yuan, M. Piacentini, B. Zhivotovsky, G. Melino, Classification of cell death: recommendations of the nomenclature committee on cell death 2009, Cell Death Differ. 16 (2009) 3-11, https://doi.org/10.1038/cdd.2008.150.

[66] R. Edmondson, J.J. Broglie, A.F. Adcock, L. Yang, Three-dimensional cell culture systems and their applications in drug discovery and cell-based biosensors, Assay Drug Dev. Technol. 12 (2014) 207-218, https://doi.org/10.1089/adt.2014.573.

[67] H. Lu, B.M. Blunden, W. Scarano, M. Lu, M.H. Stenzel, Anti-metastatic effects of RAPTA-C conjugated polymeric micelles on two-dimensional (2D) breast tumor cells and three-dimensional (3D) multicellular tumor spheroids, Acta Biomater. 32 (2016) 68-76, https://doi.org/10.1016/j.actbio.2015.12.020.

[68] J. Friedrich, C. Seidel, R. Ebner, L.A. Kunz-Schughart, Spheroid-based drug screen: considerations and practical approach, Nat. Protoc. 4 (2009) 309-324, https://doi. org/10.1038/nprot.2008.226.

[69] F. Hirschhaeuser, H. Menne, C. Dittfeld, J. West, W. Mueller-Klieser, L.A. KunzSchughart, Multicellular tumor spheroids: an underestimated tool is catching up again, J. Biotechnol. 148 (2010) 3-15, https://doi.org/10.1016/j.jbiotec.2010.01. 012 .

[70] E. Gottfried, L.A. Kunz-Schughart, R. Andreesen, M. Kreutz, Brave little world: spheroids as an in vitro model to study tumor-immune-cell interactions, Cell Cycle 5 (2006) 691-695, https://doi.org/10.4161/cc.5.7.2624.

[71] W. Fayad, S. Brnjic, D. Berlind, S. Blixt, M.C. Shoshan, M. Berndtsson, M.H. Olofsson, S. Linder, Restriction of cisplatin induction of acute apoptosis to a subpopulation of cells in a three-dimensional carcinoma culture model, Int. J. Cancer 125 (2009) 2450-2455, https://doi.org/10.1002/ijc.24627. 